\title{
Nuevos aportes para la delimitación de la base regional de recursos líticos de la provincia de Entre Ríos: relevamiento de afloramientos primarios y caracterización microscópica de rocas siliciclásticas
}

\author{
Eduardo Apolinaire*, Carola Castiñeira Latorre "** y Mariano \\ Bonomo
}

Recibido:

15 de marzo de 2018

Aceptado:

1 de octubre de 2018

\section{Resumen}

En este trabajo se presentan los resultados de los trabajos de campo y de laboratorio llevados a cabo sobre una amplia diversidad de rocas plausibles de ser aprovechadas como recursos líticos que se encuentran naturalmente disponibles en el sur del nordeste argentino. El objetivo general de estos estudios es el desarrollo de un marco de referencia útil para la interpretación de los conjuntos líticos del sector bajo estudio. Para esto, se desarrolla una síntesis que recopila información tanto arqueológica como geológica junto a datos novedosos generados mediante prospecciones a escala regional y estudios petrográficos a nivel micro y macroscópico. De este modo fue posible precisar, desde un enfoque arqueológico, la localización y la accesibilidad espacial de diversos afloramientos rocosos y caracterizar la morfología, estructura y composición mineralógica de una amplia diversidad de fuentes de materia prima lítica. Finalmente, se hizo foco sobre las características de una de las materias primas más frecuentemente mencionadas en la literatura arqueológica, las areniscas, y se llevaron a cabo estudios tendientes a discriminar la procedencia de las mismas y las transformaciones que estas rocas pudieron sufrir por termoalteración en el pasado prehispánico.

* División Arqueología, Facultad de Ciencias Naturales y Museo, Universidad Nacional de La Plata (UNLP). Paseo del Bosque s/n (CP B19ooFWA) La Plata, Buenos Aires, Argentina. E-mail: eapolinaire@gmail.com

** División Mineralogía, Facultad de Ciencias Naturales y Museo, Universidad Nacional de La Plata (UNLP) - CONICET.

Paseo del Bosque s/n (CP B19ooFWA) La Plata, Buenos Aires, Argentina. E-mail: Carolacl2004@gmail.com

*** División Arqueología, Facultad de Ciencias Naturales y Museo, Universidad Nacional de La Plata (UNLP) - CONICET.

Paseo del Bosque s/n (CP B19ooFWA) La Plata, Buenos Aires, Argentina. E-mail: mbonomo@fcnym.unlp.edu.ar

\section{Palabras clave}

Recursos líticos Materia prima Entre Ríos Tecnología lítica Petrografía Estudios experimentales 


\title{
New contributions to the characterization of the regional lithic resource base in Entre Ríos Province: Regional survey of lithic outcrops and microscopic characterization of siliciclastic rocks
}

\begin{abstract}
Keywords

Lithic resources

Raw material

Entre Ríos

Lithic technology

Petrography

Experimental studies

In this paper, we present the results of fieldwork and laboratory studies developed on a wide range of rock types found in the southern sector of northeastern Argentina. These rocks could feasibly be employed as lithic raw material. The main aim of this study was to develop a useful reference framework for the interpretation of lithic assemblages recovered from the study area. We present a synthesis of the archaeological and geological data available, combined with new research generated through extensive surveys and micro and macro-scale petrographic analysis. As a result, we were able to specify the location and spatial accessibility of several lithic outcrops, and to identify the morphology, structure and mineral composition of a large number of lithic raw material sources. Finally, we characterized one of the most frequently found raw materials in the extant archaeological literature: sandstone. We carried out thin-section analyses in order to establish its provenance, as well as to assess the transformations these rocks suffered due to thermal alteration.
\end{abstract}

\section{Introducción}

El registro arqueológico de la provincia de Entre Ríos presenta una importante diversidad de materias primas líticas, tales como rocas criptocristalinas (calcedonias, xilópalos, calizas silicificadas), ígneas (basaltos y granitos), siliciclásticas sedimentarias y metamórficas (cuarcitas y areniscas) y rocas carbonáticas (Apolinaire, en prensa; Bonomo y Blasi, 2010; Hocsman, 1999; Loponte, Tchilinguirian y Silvestre, 2011). Las trayectorias tecnológicas de estas rocas incluyeron, por un lado, la reducción por talla para la obtención tanto de filos cortantes como de instrumentos con elevada formatización, como puntas, raederas y raspadores (Apolinaire, Bastourre y Angrizani, 2016; Castro, 2012; Hocsman, 1999; Rodríguez, 2001). Por otro lado, las técnicas de picado, abrasión y pulido se aplicaron para la elaboración de bolas, manos, molinos, masas estrelladas y hachas, entre otros instrumentos (Apolinaire, 2017; Bonomo y Blasi, 2010; Rodríguez, 2001). Finalmente, algunas de estas rocas fueron utilizadas como soporte para la elaboración de adornos (pendientes, cuentas, tembetás) y arte móvil (piedras grabadas) (Apolinaire, 2017; Bonomo, 2012). Se ha propuesto que el aprovisionamiento de estas rocas se realizó a partir de estrategias que implicaron tanto la explotación directa de fuentes locales como la obtención de rocas alóctonas a partir de amplios circuitos de movilidad e intercambio (Apolinaire, 2017). Sin embargo, para abordar esta problemática hasta hace poco tiempo solo se disponía de bibliografía geológica generada a escala espacial suprarregional como fuente de información sobre los afloramientos de materia prima. Mediante este procedimiento no es posible precisar las áreas de aprovisionamiento más allá de los amplios espacios donde afloran las formaciones geológicas, las cuales presentan una gran extensión e incluyen numerosas facies, no todas litificadas o de igual calidad para la manufactura. Los sectores de aprovisionamiento recurrentemente mencionados en la bibliografía se vinculan fundamentalmente con tres áreas: el río Uruguay y el territorio de la República Oriental del Uruguay (R.O.U), el río Paraná y la margen oriental del Río de la Plata interior.

En búsqueda de una mayor precisión en la delimitación de las áreas de aprovisionamiento se desarrollaron más recientemente algunos estudios que abordaron los afloramientos 
naturales con objetivos netamente arqueológicos. Sin embargo, la mayor parte de ellos se focalizaron en sectores puntuales del paisaje - la Formación Puerto Yeruá en el Parque Nacional El Palmar (Loponte et al., 2011), la Formación Ituzaingó en el arroyo Las Conchas (Hocsman, 2015) y las Formaciones Paraná e Ituzaingó en el sector sur de la cuenca del río Paraná (Bonomo y Blasi, 2010; Hocsman, 2015) — o bien abordaron depósitos particulares a lo largo de amplias extensiones espaciales - los depósitos secundarios de rodados del río Uruguay inferior (Apolinaire, en prensa) y las calizas silicificadas del Queguay a lo largo de la R.O.U. (Martínez, Veroslavsky y Cabrera, 2015). De esta manera, no se dispone hasta el momento de trabajos que aborden desde un enfoque regional y de manera sistemática la gran variabilidad de recursos líticos aptos para la manufactura de herramientas.

En este trabajo se presenta una síntesis que conjuga la información disponible (tanto arqueológica como geológica) con un relevamiento sistemático en campo y el posterior análisis de muestras de roca recolectadas en diferentes afloramientos primarios a lo largo de la provincia de Entre Ríos. Se realizó una caracterización petrográfica macroscópica de dichas muestras y se analizó la distribución espacial de las distintas clases de roca. Se puso especial énfasis en el análisis de las areniscas, rocas recurrentemente citadas en los trabajos arqueológicos a lo largo de la provincia (Apolinaire et al., 2016; Buc y Silvestre, 2010; Castro, 2013; Castro y Angrizani, 2014). La existencia en la región de varias formaciones con este tipo de litología, junto a las variaciones faciales que una misma unidad sedimentaria puede presentar, dificultan la posibilidad de definir los locus geográficos de procedencia de las areniscas recuperadas en los sitios arqueológicos (Bonomo y Blasi, 2010). En este sentido, se llevaron a cabo análisis petrográficos sobre lámina delgada a los fines de aportar información relevante para la identificación de la procedencia de estas rocas. De forma complementaria, se compararon estos datos con cortes realizados sobre artefactos arqueológicos recuperados en el sudoeste de Entre Ríos. Por otra parte, en varios contextos arqueológicos las areniscas presentan evidencias de alteración térmica, modificación que puede transformar diversas propiedades de estas rocas y por ende su aptitud para la manufactura (Franzen, Krause, Siedel y Ullrich, 2012; Jeske, Winkler y Blodgett, 2010; Nami, Cattáneo y Pupio, 2000). Teniendo esto en cuenta, se analizaron las modificaciones microscópicas que sufren las areniscas bajo el efecto de la alteración térmica. En suma, el objetivo general de estos estudios es desarrollar un marco de referencia útil para la interpretación del registro arqueológico respecto a temas tales como aprovisionamiento, movilidad, intercambio de bienes y estrategias tecnológicas implementadas por los diferentes grupos humanos que habitaron el territorio entrerriano en el pasado prehispánico.

\section{Estratigrafía del área}

A lo largo del territorio de la actual provincia de Entre Ríos y áreas circundantes la literatura geológica ha descrito una gran variedad de afloramientos naturales que presentan rocas potencialmente útiles para la confección de diversos tipos de artefactos (de impacto, corte, molienda, materiales constructivos, soportes de arte mueble, entre otros). A continuación, se desarrolla una síntesis de esta información, con el objetivo de brindar una primera definición de las litologías disponibles en la región y las principales áreas de abastecimiento donde las materias primas líticas pudieron ser obtenidas.

\section{El Complejo Martín García}

En la isla Martín García y en la margen izquierda del río de la Plata afloran principalmente rocas ígneo-metamórficas precámbricas que conforman el Complejo Martín García y que se incluyeron en el cratón del Río de la Plata por edad y evolución geológica (Dalla Salda, 1999). Este complejo consiste en una serie de metamorfitas, 
principalmente anfibolitas, a las que acompañan gneises, piroxenitas y esquistos. Estos últimos suelen presentar fenómenos de migmatización e intrusión de escasos y pequeños filones graníticos (Aceñolaza, 2007; Dalla Salda, 1999). Las rocas del complejo fueron sometidas a eventos de deformación dúctil que provocaron la lenticularidad característica de estas metamorfitas y generaron una recristalización profunda con la consecuente neoformación de microclinos, plagioclasas y cuarzos en las migmatitas. Con posterioridad a los principales eventos metamórficos ocurrió la elevación del complejo a niveles corticales superiores, donde se produjo la intrusión de plutones menores graníticos a tonalíticos (Dalla Salda, 1999).

\section{Formación Botucatú}

Esta formación de edad mesozoica está compuesta por areniscas cuarzosas a cuarzofeldespáticas de color rosado, amarillento o rojizo, bien seleccionadas y laminadas, con cemento silíceo y segregaciones férricas (Iriondo y Kröhling, 2008; Silva Busso y Fernández Garrasino, 2004). Esta formación es equivalente a la Fm. Solari (Herbst, 1971) y parcialmente a la Fm. Tacuarembó de la R.O.U. Aflora a lo largo del río Uruguay desde la provincia de Misiones hasta la ciudad de Concordia. En la provincia de Entre Ríos se encuentra intercalada con los basaltos de la Fm. Serra Geral. En estas intercalaciones se observan niveles con fenómenos de cocción, que dan lugar a una cuarcita de color algo más oscuro y niveles silicificados (Aceñolaza, 2007).

\section{Formación Serra Geral}

Se designa como Fm. Serra Geral a las rocas que se originaron durante un acontecimiento eruptivo basáltico dominantemente tolético y de magnitud regional que cubrió parte de los territorios de Argentina, Brasil, Uruguay y Paraguay durante el Jurásico superior. Esta formación aflora a lo largo del curso del río Uruguay hasta la ciudad de Concordia. Las rocas dominantes son basaltos de tipo toleítico que se disponen en forma de coladas lávicas, filones capa y diques (Aceñolaza, 2007). Estos basaltos presentan colores pardorojizos a grisáceos y negros. Las porciones basales y subsuperficiales de cada derrame presentan una textura afanítica, compacta y con numerosas diaclasas horizontales. La porción central, de enfriamiento lento, consta de basaltos densos de coloración gris-negruzca con fuerte tenacidad y textura holocristalina (Gentili y Rimoldi, 1979). Por encima de éstos, en el techo de cada colada, se desarrolla un basalto alveolar que presenta vesículas y amígdalas frecuentemente rellenas de calcedonia, ópalo o cuarzo. El relleno de estos alveolos se produjo por la segregación generalizada de sílice y sílice hidratada hacia el Terciario inferior. Además, pueden encontrarse vesículas rellenas de carbonatos, hematita, clorita o cobre nativo. Los saltos ("restingas") del río Uruguay corresponden a frentes de coladas compuestos por estos basaltos alveolares, los cuales constituyen los últimos afloramientos naturales de esta formación hacia el sur (Gentili y Rimoldi, 1979). La meteorización y erosión de los basaltos produjo la liberación de las concreciones silíceas, que fueron transportadas por el río Uruguay generando grandes depósitos de rodados (Iriondo y Kröhling, 2008).

\section{Formación Puerto Yeruá}

Sobre la Fm. Serra Geral apoya en discordancia la Fm. Puerto Yerúa (De Alba y Serra, 1959), que se compone de depósitos clásticos y carbonáticos de origen fluvial datados en el Cretácico superior (von Huene, 1929). Esta formación aflora de forma discontinua en el valle fluvial del río Uruguay (Gentili y Rimoldi, 1979). La sedimentación cretácica de la cuenca comienza con una sucesión siliciclástica granodecreciente desde conglomerados hasta pelitas, dominantemente arenosa, con colores rojizos o rosados. Esta sucesión se da en forma de cuerpos lenticulares de hasta $4 \mathrm{~m}$ de potencia con estratificación entrecruzada planar y en artesa. Estas sedimentitas se habrían depositado 
en un ambiente fluvial desarrollado en una planicie aluvial de cursos migrantes con baja a moderada sinuosidad (Aceñolaza, 2007; Tófalo y Pazos, 2002). Estas rocas presentan varios procesos de calcretización debido a los cuales es posible encontrar, según el contenido de carbonato de calcio, desde epiclastitas a calcretes nodulares, macizos, laminares y brechosos. Los calcretes tendrían una génesis mixta vinculada a procesos pedogenéticos, de evaporación de cuerpos de agua y movimientos capilares y laterales de la capa freática (Tófalo y Pazos, 2002).

En la R.O.U la secuencia que compone la Fm. Puerto Yeruá es dividida en las Formaciones Guichón, Mercedes, Queguay y Asencio (Tófalo y Pazos, 2010; Tófalo, Pazos, Bettucci, 2011). Es posible observar grandes similitudes entre las epiclastitas de la sección inferior de la Fm. Puerto Yerúa y lo descrito para la Fm. Mercedes, así como entre los calcretes superiores de la Fm. Puerto Yerúa y los calcretes de la Fm. Queguay. Si bien no es clara la presencia de la Fm. Mercedes y la Fm. Queguay en Argentina, es interesante señalar la presencia de niveles calcretizados por sobre la secuencia fluvial post-basáltica cretácica en el Parque Nacional El Palmar (Aceñolaza, 2007). Los depósitos carbonáticos de la Fm. Queguay presentan facies silicificadas (Santa Ana, Veroslavsky, Etchebehere y Saad, 2013) donde se observa un reemplazo del carbonato por sílice o infiltraciones de sílice de tamaños variables. Las formas de sílice más comunes son el ópalo marrón y el cuarzo microcristalino, con proporciones menores de calcedonia y cuarzo (Tófalo y Morrás, 2009; Tófalo y Pazos, 2010). Los niveles silcretizados del Parque Nacional El Palmar tienen un desarrollo discreto y se presentan como vetas discontinuas o nódulos aislados. Loponte y colaboradores (2011) describen petrográficamente estos depósitos en los que identifican al menos nueve facies petrográficas que incluyen: silcretes masivos, silcretes de textura brechosa, niveles arcillosos silcretizados, calcretes poco silicificados y calizas masivas.

\section{Formación Paraná}

La Formación Paraná (Bravard, 1858) corresponde a los sedimentos depositados durante una gran ingresión marina que habría cubierto parte del noreste argentino, oeste de Uruguay y parte de Paraguay durante el Terciario. Durante este suceso, denominado "Mar Paranaense" o "Mar Entrerriense", se habrían depositado en un comienzo arcillas correspondientes a un mar profundo y posteriormente depósitos de arcillas arenosas y arenas finas asociadas a un mar somero (Bertolini, Bahler y Zabalegui, 2009). Esta formación aflora hoy día sobre la margen izquierda del río Paraná al sur de la ciudad de Paraná y hasta las inmediaciones de la ciudad de Victoria. Otros afloramientos menores se observan en arroyos transversales a las barrancas del río tales como los arroyos Doll, La Ensenada, Salto, Las Conchas y Las Arañas. Esta unidad se define como una sucesión de arenas, limolitas y arcilitas gris verdosas a las que se superponen arenas arcillosas y calizas organogénicas (Aceñolaza, 2007). En algunos sectores se presentan niveles de areniscas cuarzosas finas de colores blanquecinos, amarillentos, grises y verdes, fuertemente cementadas por carbonatos (Bertolini, Bahler y Zabalegui, 2009; Bonomo y Blasi, 2010). La Fm. Paraná presenta en su capa superior una importante concentración de bioclastos formados por organismos marinos y en menor medida continentales. Este nivel es subyacente a la Formación Ituzaingó (Torra, 1999).

En la localidad de Punta Gorda aflora una de las secciones más representativas de esta unidad. Este perfil se conforma de base a techo por un metro de limos y arenas finas masivas sobre las cuales se disponen en discordancia dos cuerpos lentiformes con bioclastos. La capa inferior, de naturaleza silícea, consiste en una calcarenita amarillenta compuesta por individuos bien seleccionados, redondeados a subredondeados. Sobre esta capa se dispone un nivel bioclástico con base erosiva que porta coquinas muy cementadas. La sección culmina con una capa de material heterolítico similar al de la base de la unidad. Estas últimas unidades se habrían depositado hacia el Mioceno 
superior en un ambiente marino somero con salinidad normal (Iriondo, 1973; Pérez, 2013).

\section{Formación Ituzaingó}

La Formación Ituzaingó ha sido referida en gran parte de la literatura geológica a sedimentos continentales de origen fluvial desarrollados posteriormente a las fases regresivas del "Mar Paranaense". Sin embargo, su origen y edad han sido ampliamente discutidos. Para Herbst y colaboradores (2000) esta unidad se habría depositado en el lapso Plioceno-Pleistoceno y su origen correspondería a los depósitos fluviales de un río de morfología semejante al Paraná al cual llamaron "Paleorío Ituzaingó". Torra (2009), en cambio, retrotrae la edad de estos depósitos al Mioceno superior y plantea un origen peritidial, a partir de las estructuras internas observadas en esta formación (Torra, 1999). De acuerdo con esta propuesta, la Fm. Ituzaingó se habría desarrollado durante la misma transgresión miocena que la Fm. Paraná (Torra, 2009).

Los afloramientos de la Fm. Ituzaingó se extienden desde la localidad homónima en el norte de la provincia de Corrientes hasta la ciudad de Paraná en Entre Ríos (Brunetto, Noriega y Brandoni, 2013; Herbst, 2000). Sin embargo, esta unidad estaría distribuida de modo más amplio en el subsuelo de la provincia de Entre Ríos. Particularmente en la cuenca del río Gualeguay y el norte de la provincia de Buenos Aires, el paquete arenoso identificado como la Fm. Puelche sería un equivalente de la Fm. Ituzaingó. Esta formación consiste en una secuencia dominantemente arenosa de colores blanquecinos, amarillos y rojizos que se presenta parcialmente silicificada o con cemento ferruginoso. En la base de la secuencia se desarrollan niveles conglomerádicos con abundancia de restos fósiles (conglomerado osífero del mesopotámico) (Aceñolaza, 2007).

El perfil de la Fm. Ituzaingó en la ciudad de Paraná (La Toma Vieja) ha sido descrito por Brunetto y colaboradores (2013), quienes identificaron dos miembros separados por una paracordancia. El miembro inferior apoya en discordancia sobre la Fm. Paraná y se caracteriza por sucesiones repetidas de sedimentos arenosos gruesos y estructuras de estratificación. Estas secuencias presentan en su base intraclastos de fango contenidos en una matriz de arenas cuarzosas gruesas a medias seguidas de arenas cada vez más finas que presentan en su tope lentes pelíticos. Puede interpretarse que esta facies corresponde a acumulaciones de ciclos fluviales con variaciones en sus caudales. Esto explicaría la sucesión de paquetes repetidos conformados por depósitos pobremente seleccionados en su base, seguidos por arenas bien seleccionadas y arenas finas y fangos en el tope. Sobre el miembro inferior apoya una columna de arenas finas a medias muy bien seleccionadas que caracterizan al miembro superior. En su base se desarrollan arenas cuarzosas medias a finas de colores blanquecinos donde se intercala un estrato horizontal de pelitas grises. Sobre éste se desarrolla un paquete de arenas medias de color amarillo parduzco seguidas de arenas medias con delgadas capas de limos y arcillas. El perfil continúa con arenas bien seleccionadas de color rosado en la base y amarillo rojizo hacia el techo. Se presenta aquí una costra de color pardo formada por segregación de hierro. Sobre ésta se disponen arenas medias ocres que alternan con niveles cubiertos por óxidos de manganeso. En la parte cuspidal afloran niveles con alternancia de arenas medias claras y capas finas de fangos oscuros (Brunetto et al., 2013).

Los sectores de la Formación Ituzaingó que presentan areniscas silicificadas se encuentran en el miembro superior. Estas rocas exhiben gran variabilidad en cuanto a su grado de consolidación, desde friables a muy consolidadas. Han sido descritas dentro de perfiles de varias localidades geológicas tales como: La Toma Vieja, Puerto Curtiembre, Las Conchas y Hernandarias (Brunetto et al. 2013; Franco 2012; Herbst, 2000; Hocsman, 1999). Además de estas areniscas, en la base de esta formación se 
encuentran diversos tipos de leños fósiles (Franco, 2012; Zucol, Brea, Lutz y Anzotegui, 2004) con distintos grados de silicificación (Hocsman, 2015).

\section{Formación Salto Chico/Salto}

La Formación Salto Chico (Rimoldi, 1962), también llamada Fm. Salto en la R.O.U. (Goso, 1965), es un depósito fluvial del río Uruguay principalmente conglomerádico. Está compuesto por arenas amarillentas a rojizas con estratos lenticulares de cantos rodados y gravas de composición silícea y, en algunos sectores, presenta intercalaciones de bancos de areniscas silicificadas. Estos depósitos de rodados forman los denominados "cerros" del río Uruguay, que son relieves positivos en la terraza fluvial que perduraron gracias a la mayor resistencia a la erosión de estas lentes (Kröhling, 2009). Esta unidad apoya en discordancia erosiva sobre los basaltos de la Fm. Serra Geral o sobre las areniscas de la Fm. Puerto Yeruá y está cubierta por sedimentos eólicos del Holoceno tardío (Aceñolaza, 2007; Iriondo y Kröhling, 2008). Esta formación corresponde a una antigua llanura aluvial (actual terraza alta del río Uruguay), formada por un paleocauce que presentaba un patrón sinuoso con grandes meandros. A partir de su contenido fósil, que incluye mamíferos de edad Lujanense, se ha inferido que esta formación se habría depositado durante el Pleistoceno (Tonni, 1987), interpretación sostenida por las dataciones de termoluminiscencia que arrojaron valores de circa 80 mil años AP para la parte superior de la unidad (Kröhling, 2009). Cabe señalar que Krohling (2009) incorpora depósitos conglomeradicos holócenicos dentro de esta formación, denominándola Fm. El Palmar.

En la R.O.U., Veroslavsky y Ubilla (2007) describieron el perfil tipo de la Fm. Salto como una secuencia compuesta por cuerpos tabulares y lenticulares de areniscas medias a gruesas intercalados con areniscas conglomerádicas y areniscas de grano fino y pelitas. En cuanto a su composición mineralógica, las arenas presentan granos de cuarzo monocristalino y policristalino, feldespatos, ópalo y clastos líticos basálticos e ígneo-metamórficos cementados por sílice (cuarzo, calcedonia y ópalo) con calcita subordinada y cemento ferruginoso. Las facies minoritarias corresponden a pelitas masivas y laminadas y conglomerados compuestos por guijas y gránulos (Veroslavsky y Ubilla, 2007).

Finalmente, cabe destacar que la Fm. Salto presenta gran cantidad de troncos fósiles silicificados correspondientes tanto a gimnospermas como a angiospermas. Estos se encuentran asociados a los niveles de conglomerados y de areniscas de la unidad (Zucol et al., 2004).

\section{Metodología}

\section{Muestreo de afloramientos rocosos}

A partir del relevamiento de la bibliografía geológica es posible señalar que las fuentes de rocas duras aptas para la manufactura de artefactos se encuentran concentradas a lo largo de los dos cursos fluviales principales de la provincia de Entre Ríos. Sin embargo, existen también pequeños afloramientos discontinuos en sectores específicos de varios tributarios, como en el río Gualeguay. Teniendo en cuenta estos antecedentes, los trabajos de campo, dirigidos a la recolección de muestras de afloramientos naturales, se centraron en dos sectores: la margen izquierda del río Paraná y sus afluentes entre los departamentos La Paz y Gualeguay, y la margen derecha del río Uruguay y sus afluentes entre los departamentos Concordia y Uruguay (Figura 1, Tabla 1). En el primer sector las formaciones geológicas con rocas potencialmente útiles son la Fm. Paraná (areniscas y coquinas) y la Fm. Ituzaingó (areniscas y xilópalos). A lo largo del curso 

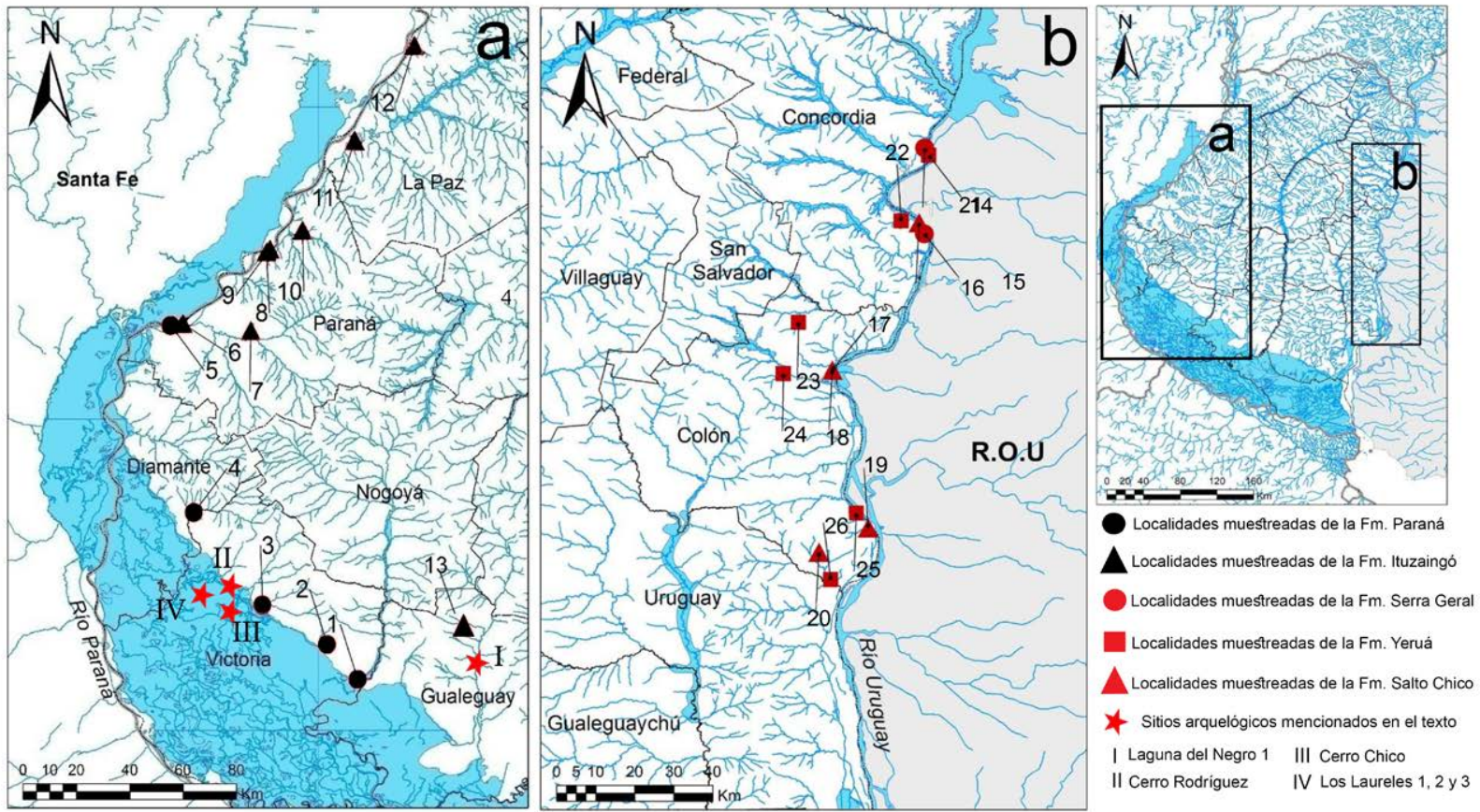

Figura 1. Afloramientos primarios de rocas relevados.

del río Uruguay, por otra parte, se muestrearon las formaciones Serra Geral (basaltos toleíticos masivos y alveolares), Puerto Yeruá (areniscas y calizas silicificadas) y El Palmar (areniscas silicificadas y xilópalos).

Se privilegió el muestreo de la mayor cantidad de afloramientos posibles y la recolección de varias muestras dentro de cada uno de ellos a los fines de obtener una mayor representatividad de la variabilidad de las facies diagenizadas de cada formación. Los principales condicionantes para la toma de muestras se vincularon con: el espesor de los afloramientos, la presentación y tamaño de las facies rocosas y la accesibilidad a los perfiles. En los casos en que fue posible se llevó a cabo un muestreo seriado a lo largo de una línea transversal a la formación geológica recuperando muestras de mano de todos los niveles diagenizados que se presentaron sobre dicha línea. Las rocas recuperadas corresponden a muestras de mano con tamaños del orden de las decenas de centímetros y pesos cercanos a $1 \mathrm{~kg}$. Durante la recolección se puso especial énfasis en la recuperación de muestras donde se preservaran las estructuras sedimentarias (Garrison, 2016; Tucker, 2003; Swanson, 1981). Es interesante señalar que, mientras que algunos de los perfiles muestreados han sido ampliamente descritos en la literatura regional (Aceñolaza, 1976, 2000; Bertolini et al., 2009; Franco y Brea, 2008; Gentili y Rimoldi, 1979; Pérez, 2013), otros afloramientos, más pequeños y discretos, no pudieron ser correlacionados estratigráficamente de forma precisa con los perfiles tipo. En estos casos las muestras no pudieron asignarse a una facies en particular y la identificación se realizó únicamente a nivel de formación geológica.

Además de los afloramientos primarios estudiados en este trabajo, es necesario aclarar que a lo largo de la costa y terrazas del Uruguay y sus afluentes existen depósitos secundarios de arena y rodados correspondientes a la Fm. El Palmar y la Fm. Concordia, cuyas características han sido estudiadas en otro trabajo (Apolinaire, en prensa). A diferencia de estos depósitos, generados a lo largo del Uruguay por agentes fluviales de trasporte y selección, los depósitos secundarios de rocas derivados de las formaciones Paraná e Ituzaingó se presentan adyacentes a los afloramientos primarios de los que derivan, debido a la falta de competencia de los cursos de agua para su transporte. 


\begin{tabular}{|c|c|c|c|c|}
\hline $\mathbf{N}^{\circ}$ & Localidad & Ubicación & Departamento & $\begin{array}{l}\text { Formación } \\
\text { Geológica }\end{array}$ \\
\hline 1 & Afloramientos de la Ruta Provincial $N^{\circ} 11$ & $32^{\circ} 50^{\prime} 13,43^{\prime \prime} \mathrm{S} / 59^{\circ} 52^{\prime} 5,57^{\prime \prime O}$ & Victoria & Fm. Paraná \\
\hline 2 & Afloramientos en la Cantera de Vialidad & $32^{\circ} 43^{\prime} 28,88^{\prime \prime} \mathrm{S} / 59^{\circ} 58^{\prime} 12,77^{\prime \prime} \mathrm{O}$ & Victoria & Fm. Paraná \\
\hline 3 & Afloramientos del Cerro La Matanza & $32^{\circ} 35^{\prime} 54,31^{\prime \prime S} / 60^{\circ} 11^{\prime} 19,76^{\prime \prime O}$ & Victoria & Fm. Paraná \\
\hline 4 & Afloramientos del Arroyo Doll & $32^{\circ} 18^{\prime} 3,53^{\prime \prime} \mathrm{S} / 60^{\circ} 25^{\prime} 10,79^{\prime \prime O}$ & Diamante & Fm. Paraná \\
\hline 5 & Barrancas del Paraná en La Toma Vieja & $31^{\circ} 42^{\prime} 9^{\prime \prime S} / 60^{\circ} 28^{\prime} 47,9^{\prime \prime} \mathrm{O}$ & Paraná & Fm. Paraná \\
\hline 6 & Barrancas del Paraná en La Toma Vieja & $31^{\circ} 42^{\prime} 9,2^{\prime \prime} \mathrm{S} / 60^{\circ} 28^{\prime} 44,6^{\prime \prime} \mathrm{O}$ & Paraná & Fm. Ituzaingó \\
\hline 7 & Afloramientos del lecho del Arroyo Carmona & $31^{\circ} 43^{\prime} 0,6^{\prime \prime} \mathrm{S} / 60^{\circ} 13^{\prime} 41,9^{\prime \prime O}$ & Paraná & Fm. Ituzaingó \\
\hline 8 & Barrancas del Paraná en la localidad de Curtiembres & $31^{\circ} 27^{\prime} 21,62^{\prime \prime} \mathrm{S} / 60^{\circ} 09^{\prime} 49,7^{\prime \prime O}$ & Paraná & Fm. Ituzaingó \\
\hline 9 & Afloramientos del arroyo Curtiembre & $31^{\circ} 27^{\prime} 49,3^{\prime \prime} \mathrm{S} / 60^{\circ} 10^{\prime} 29,3^{\prime \prime O}$ & Paraná & Fm. Ituzaingó \\
\hline 10 & Afloramientos del arroyo Del Manantial & $31^{\circ} 23^{\prime} 41,7^{\prime \prime} \mathrm{S} / 60^{\circ} 03^{\prime} 13,8^{\prime \prime O}$ & Paraná & Fm. Ituzaingó \\
\hline 11 & Afloramientos del Riacho Alcaraz & $31^{\circ} 6^{\prime} 23,34^{\prime \prime} \mathrm{S} / 59^{\circ} 52^{\prime} 43,70^{\prime \prime} \mathrm{O}$ & La Paz & Fm. Ituzaingó \\
\hline 12 & Barrancas del Paraná en la Localidad de La Paz & $30^{\circ} 48^{\prime} 03,4^{\prime \prime S} / 59^{\circ} 40^{\prime} 39,7^{\prime \prime O}$ & La Paz & Fm. Ituzaingó \\
\hline 13 & Afloramientos en las Barrancas del Arroyo Jacinta & $32^{\circ} 42^{\prime} 53,9^{\prime \prime} \mathrm{S} / 59^{\circ} 9^{\prime} 14,69^{\prime \prime O}$ & Gualeguay & Fm. Ituzaingó \\
\hline 14 & Restinga de Salto Chico & $31^{\circ} 21^{\prime} 38,62^{\prime \prime S} / 57^{\circ} 59^{\prime} 40,79^{\prime \prime O}$ & Concordia & Fm. Serra Geral \\
\hline 15 & Restinga de Paso del Hervidero & $31^{\circ} 33^{\prime} 28,72^{\prime \prime} \mathrm{S} / 57^{\circ} 59^{\prime} 43,87^{\prime \prime O}$ & Concordia & Fm. Serra Geral \\
\hline 16 & Barrancas del río Uruguay en la Localidad de Puerto Yeruá & $31^{\circ} 31^{\prime} 56,61^{\prime \prime S} / 58^{\circ} 0^{\prime} 27,93^{\prime \prime O}$ & Concordia & Fm. Puerto Yeruá \\
\hline 17 & $\begin{array}{l}\text { Barrancas del río Uruguay al norte de la Calera Barquín } \\
\text { (Parque Nacional El Palmar) }\end{array}$ & $31^{\circ} 52^{\prime} 18,33^{\prime \prime} \mathrm{S} / 58^{\circ} 12^{\prime} 27,88^{\prime \prime} \mathrm{O}$ & Colón & Fm. Puerto Yeruá \\
\hline 18 & $\begin{array}{l}\text { Barrancas del río Uruguay al sur de la calera de Barquín en } \\
\text { el Parque Nacional El Palmar }\end{array}$ & $31^{\circ} 52^{\prime} 18,33^{\prime \prime} \mathrm{S} / 58^{\circ} 12^{\prime} 27,88^{\prime \prime O}$ & Colón & Fm. Puerto Yeruá \\
\hline 19 & $\begin{array}{l}\text { Afloramientos en la desembocadura del arroyo de La } \\
\text { Leche }\end{array}$ & $32^{\circ} 14^{\prime} 5,99^{\prime \prime} \mathrm{S} / 58^{\circ} 7^{\prime} 29,14^{\prime \prime O}$ & Colón & Fm. Puerto Yeruá \\
\hline 20 & $\begin{array}{l}\text { Barrancas con afloramientos al norte del arroyo El Pelado } \\
\text { en las inmediaciones de la localidad de Colonia Hughes }\end{array}$ & $32^{\circ} 19^{\prime} 4,4^{\prime \prime} \mathrm{S} / 58^{\circ} 12^{\prime} 55,8^{\prime \prime} \mathrm{O}$ & Colón & Fm. Puerto Yeruá \\
\hline 21 & $\begin{array}{l}\text { Barrancas del río Uruguay al norte de la ciudad de } \\
\text { Concordia }\end{array}$ & $31^{\circ} 22^{\prime} 37,9^{\prime \prime} \mathrm{S} / 57^{\circ} 59^{\prime} 8,7^{\prime \prime O}$ & Concordia & Fm. Salto Chico \\
\hline 22 & $\begin{array}{l}\text { Afloramientos en el camino de acceso a la localidad de } \\
\text { Puerto Yeruá }\end{array}$ & $31^{\circ} 31^{\prime} 42,7^{\prime \prime} \mathrm{S} / 58^{\circ} 2^{\prime} 56,6^{\prime \prime} \mathrm{O}$ & Concordia & Fm. Salto Chico \\
\hline 23 & $\begin{array}{l}\text { Afloramientos sobre la margen izquierda del arroyo San } \\
\text { Antonio }\end{array}$ & $31^{\circ} 45^{\prime} 43,5^{\prime \prime} \mathrm{S} / 58^{\circ} 17^{\prime} 8,4^{\prime \prime O}$ & Colón & Fm. Salto Chico \\
\hline 24 & Afloramiento de la margen izquierda del arroyo La Capilla & $31^{\circ} 51^{\prime} 36,25^{\prime \prime} \mathrm{S} / 58^{\circ} 19^{\prime} 35,3^{\prime \prime O}$ & Colón & Fm. Salto Chico \\
\hline 25 & Afloramientos de la margen izquierda del arroyo Artalaz & $32^{\circ} 12^{\prime} 5,8^{\prime \prime} \mathrm{S} / 58^{\circ} 9^{\prime} 9^{\prime \prime O}$ & Colón & Fm. Salto Chico \\
\hline 26 & Margen derecha del arroyo Urquiza & $32^{\circ} 21^{\prime} 15^{\prime \prime} \mathrm{S} / 58^{\circ} 12^{\prime} 40^{\prime \prime O}$ & Uruguay & Fm. Salto Chico \\
\hline
\end{tabular}

Tabla 1. Muestras de roca recolectadas durante las prospecciones.

Debido a esto, sus características son generalmente asimilables a las de sus afloramientos parentales, por lo que no serán tratados específicamente.

\section{Petrografía}

A continuación, se precisan algunos términos geológicos utilizados a lo largo del trabajo y se presentan los criterios metodológicos generales utilizados para la identificación y caracterización macroscópica de los afloramientos relevados. Posteriormente, se describen las técnicas utilizadas durante los estudios microscópicos de rocas silicoclásticas y algunos lineamientos básicos para abordar las modificaciones que pueden sufrir las mismas al ser sometidas a alteración térmica.

La clasificación de las rocas ígneas se realizó siguiendo los lineamientos planteados por Frost y Frost (2014). Los basaltos en particular pueden dividirse, en términos generales, en dos grandes grupos: alcalino y toleítico (Best, 2003; Frost y Frost, 2014), siendo este último el único tipo de basalto presente en la región. Las variables que se tuvieron en cuenta para la caracterización de los basaltos son el color, la fábrica y la calidad para la 
talla. En cuanto a la fábrica, los basaltos pueden clasificarse en vesiculares o masivos de acuerdo a la presencia o ausencia de vesículas o cavidades, siendo los primeros menos densos y de composición más volátil que los segundos. La calidad para la talla se definió teniendo en cuenta principalmente la existencia de alveolos, el grado de meteorización y la presencia de fracturas o rasgos planares.

Por otra parte, los cherts refieren de modo general a rocas silíceas amorfas o de grano muy fino que pueden corresponder a orígenes muy diferentes (inorgánicos, orgánicos, volcánicos e hidrotermales) (Tucker, 2002). Estas rocas se componen de sílice en diferentes grados de cristalización, desde ópalos hasta cuarzos. Estos últimos asumen dos formas: el megacuarzo, que se utiliza para denominar tanto cristales como geodas y vetas, y el microcuarzo. Este último se divide, a su vez, en cuarzo microcristalino (agregados de granos equidimensionales de 1 a 5 micrones) y calcedonia, donde el cuarzo forma agregados radiales de cristales aciculares (Folk, 1980). La mayoría de estas rocas silíceas presentan porcentajes minoritarios de impurezas mecánicas que brindan a la roca diferentes tonalidades, lo que ha llevado a reconocer dentro de los cherts al pedernal (negro debido a la presencia de materia orgánica), el jaspe verde (clorita), el jaspe rojo (hematita), la novaculita (blanco debido a inclusiones fluidas) y la calcedonia (translúcida o grisácea) (Boggs, 2009; Folk, 1980). Los cherts se presentan usualmente en los afloramientos como cherts nodulares o en capa. Los primeros suelen desarrollarse hospedados en rocas carbonáticas o basálticas. Los cherts en capas, por su parte, presentan una génesis muy discutida y se asocian tanto a orígenes biogénicos como ígneos (Tucker, 2002). En la cuenca del río Uruguay el origen de los cherts vinculados a la Fm. Puerto Yeruá (Argentina) o Fm. Mercedes/Queguay (Uruguay) ha sido discutida en profundidad por Tófalo y Pazos (2010) y Tófalo y colaboradores (2011), como se desarrolló previamente. En el caso de los cherts se relevó el color, la morfología (nodular o laminar) y la calidad para la talla. Esta se definió principalmente en base a la homogeneidad de la roca, teniendo en cuenta la presencia de venillas, cristales u otras inclusiones.

Finalmente, los sedimentos silicoclásticos diagenizados incluyen una amplia variedad de rocas que van desde lutitas de grano muy fino a conglomerados y brechas de grano grueso, pasando por las areniscas (Tucker, 2002). Estas últimas se definen como rocas formadas por la litificación de depósitos silicoclásticos cuyos clastos presentan tamaños entre $1 / 16$ y $2 \mathrm{~mm}$ según la escala de Wentworth. Las areniscas se componen de una porción detrítica, el esqueleto, y de vacíos o poros. Estos espacios pueden encontrarse rellenados ya sea por cemento o por una matriz de clastos de menor tamaño que el esqueleto. Estas características permiten clasificar las muestras en base a su petrografía y calidad para la talla (Hocsman, 2015). La descripción macroscópica de las rocas silicoclásticas se realizó siguiendo la metodología de campo propuesta por Tucker (2003) y tuvo en cuenta el color, la estructura sedimentaria (p. ej. presencia de entrecruzamiento, ondulaciones), la textura y la mineralogía de los clastos y cementos. La calidad para la talla se testeó experimentalmente en campo considerando la aptitud de la roca para obtener filos. Se tuvieron en cuenta las categorías de calidad propuestas por Hocsman (2015) para las areniscas del Paraná medio a partir de la porosidad, el tamaño de grano y el tipo de cemento. En los casos en que se realizaron cortes de lámina delgada estas características se definieron con mayor precisión a nivel microscópico.

\section{Análisis microscópico de las rocas silicoclásticas}

Como se mencionó previamente, las rocas ígneas y los cherts se presentan en sectores acotados de la región, en afloramientos relativamente discretos. Este no es el caso de las rocas silicoclásticas, que afloran a lo largo del Paraná, el Uruguay y algunos de sus tributarios. Por este motivo, se tornó necesario realizar estudios petrográficos 
sobre lámina delgada de muestras provenientes de distintos sectores, con el objetivo de precisar su caracterización y definir sus aptitudes tecnológicas y funcionales. A partir de la clasificación y descripción de muestras de mano desarrollada macroscópicamente y con lupa binocular, se seleccionaron 13 muestras de areniscas representativas de la variabilidad (respecto a la litología, tamaño de grano, cemento, color, impurezas y estructuras sedimentarias, entre otras) presente en los afloramientos. Asimismo, se analizaron tres artefactos recuperados en estratigrafía en el sitio Laguna del Negro 1 (LDN1) (Apolinaire, 2017; Apolinaire y Castiñeira, en prensa; Bastourre y Apolinaire, 2017), sitio ubicado en las llanuras interiores entrerrianas (Figura 1). Es importante señalar que los tres artefactos sobre los que se efectuaron cortes de lámina delgada fueron seleccionados por considerarlos representativos de la variabilidad macroscópica que exhiben las areniscas en este conjunto arqueológico, incluyendo la presencia de rasgos de alteración térmica. Asimismo, teniendo en consideración que el conjunto de artefactos elaborados sobre arenisca de LDN1 consta solo de 105 elementos, los cuales exhiben mayormente tamaños pequeños (sobre los que no pueden realizarse cortes delgados) se decidió la realización de sólo tres cortes delgados sobre artefactos que presentan escasos rasgos tecnológicos (desechos de talla).

En el marco de los estudios sobre lámina delgada también se incorporaron muestras arqueológicas provenientes de sitios del Delta Superior del Paraná. Para esto, se re-analizaron siete de las láminas delgadas presentadas por Bonomo y Blasi (2010) con el fin de profundizar su estudio y uniformizar las variables de análisis, generando información factible de ser comparada con las nuevas muestras aquí presentadas.

Se confeccionaron láminas de 0,03 $\mathrm{mm}$ de espesor a partir de los fragmentos líticos, previamente impregnados en resina epoxi. Los cortes fueron pulidos, montados en un portaobjeto y protegidos con cubre objeto. El análisis petrográfico se realizó siguiendo los lineamientos propuestos por Tucker (2002) y consistió en la observación bajo microscopía óptica de polarización (luz normal y polarizada) de la textura (tamaño de grano, selección, redondez, morfología, fábrica y contacto entre los clastos), la composición mineralógica (proporciones relativas de tipos de clasto, matriz y cemento de la muestra) y la estructura (estratificación, laminación, perforaciones, nódulos, etc.). Asimismo, se llevó a cabo la estimación de los parámetros (media, moda, desvío estándar, asimetría y curtosis) del tamaño de grano. Esta variable fue relevada a través del conteo de puntos sobre fotografías, mediante software especializado. Tanto este conteo como la estimación de las proporciones de esqueleto/cemento se realizaron utilizando el software JMicroVision v1.27 sobre diez campos para cada lámina delgada (Roduit, 2007). Finalmente, se clasificaron las muestras según contenido de cuarzo/ feldespato/líticos de acuerdo al diagrama de Dott modificado por Pettijohn (1989).

\section{Muestras experimentales}

La alteración térmica puede generar transformaciones físicas en las rocas silicoclásticas, modificando los valores de las variables que definen la calidad para la talla. Por este motivo, se llevó a cabo la alteración térmica experimental de tres muestras correspondientes a areniscas de las formaciones Paraná, Salto Chico e Ituzaingó recuperadas en las localidades 1,13 y 23 (Tabla 1). Las muestras termoalteradas fueron expuestas a temperaturas de 250 y $500{ }^{\circ} \mathrm{C}$, utilizando una mufla. Se registraron sobre estas muestras las mismas variables macroscópicas señaladas previamente para otras rocas silicoclásticas, obteniendo de esta forma descripciones de las mismas muestras en sus estados previos y posteriores a la termoalteración. Por último, la muestra procedente de la Fm. Salto Chico se analizó a partir de un corte de lámina delgada con el objetivo de relevar la incidencia de microfracturas, recristalización y cambios mineralógicos producto de la temperatura (sensu Pettijohn, 1989). Cabe destacar que 

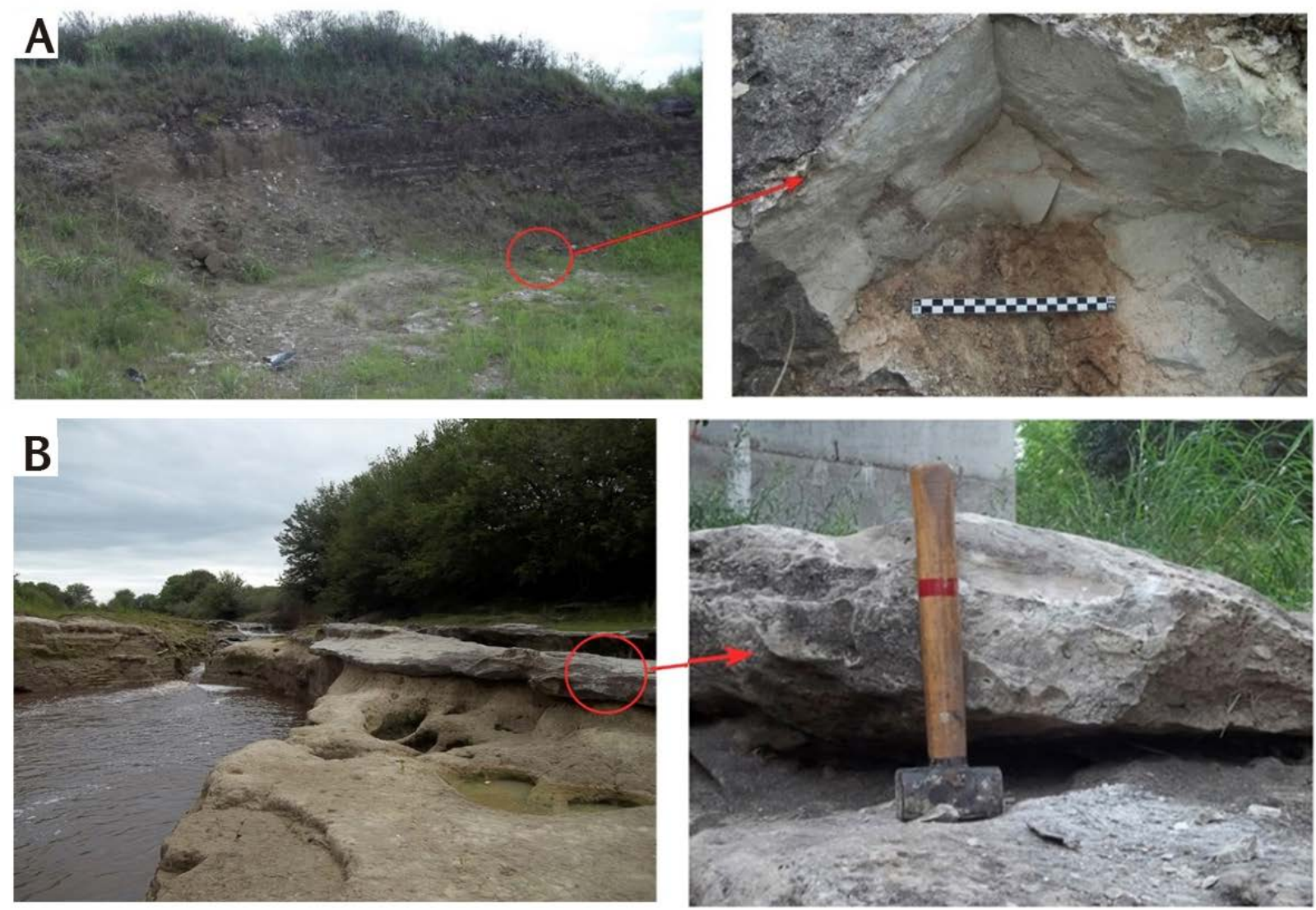

Figura 2. Afloramientos correspondientes a la Fm. Paraná.

en este último caso también se contó con un corte delgado de la muestra de modo previo a la termoalteración.

\section{Resultados}

\section{Caracterización macroscópica de los afloramientos}

Las muestras de roca recuperadas en las localidades 1 a 5 (Tabla 1), correspondientes a la formación Paraná, fueron identificadas macroscópicamente como areniscas muy tenaces cementadas por carbonatos, de tonalidades blanquecinas y granulometrías en general finas y muy finas, que gradan a limolitas, aunque en algunos afloramientos presentan tamaño de grano mediano. En las localidades 1 y 2 se disponen en cuerpos masivos de medio metro de espesor (Figura 2A) y presentan nódulos de sílice y bioclastos dentro de su estructura. Las areniscas de esta formación también pueden presentar estructuras horizontales y entrecruzadas. En las localidades 3 y 4 se presentan a modo de capas cementadas sobre niveles de pelitas verdosas (Figura $2 \mathrm{~B}$ ) mientras que en la localidad 5 se manifiestan en la base de los perfiles de la localidad La Toma Vieja por debajo de la Formación Ituzaingó. Debido a su cementación, estas rocas presentan en general una calidad de mala a regular para la talla.

En cuanto a las areniscas de la Formación Ituzaingó, se registró una amplia variabilidad a lo largo de las localidades prospectadas. Las muestras recolectadas en la localidad 6 corresponden a niveles de areniscas amarillentas poco tenaces, con tamaños de grano mediano a grueso y mala calidad para la talla. Exhiben un buen grado de selección 

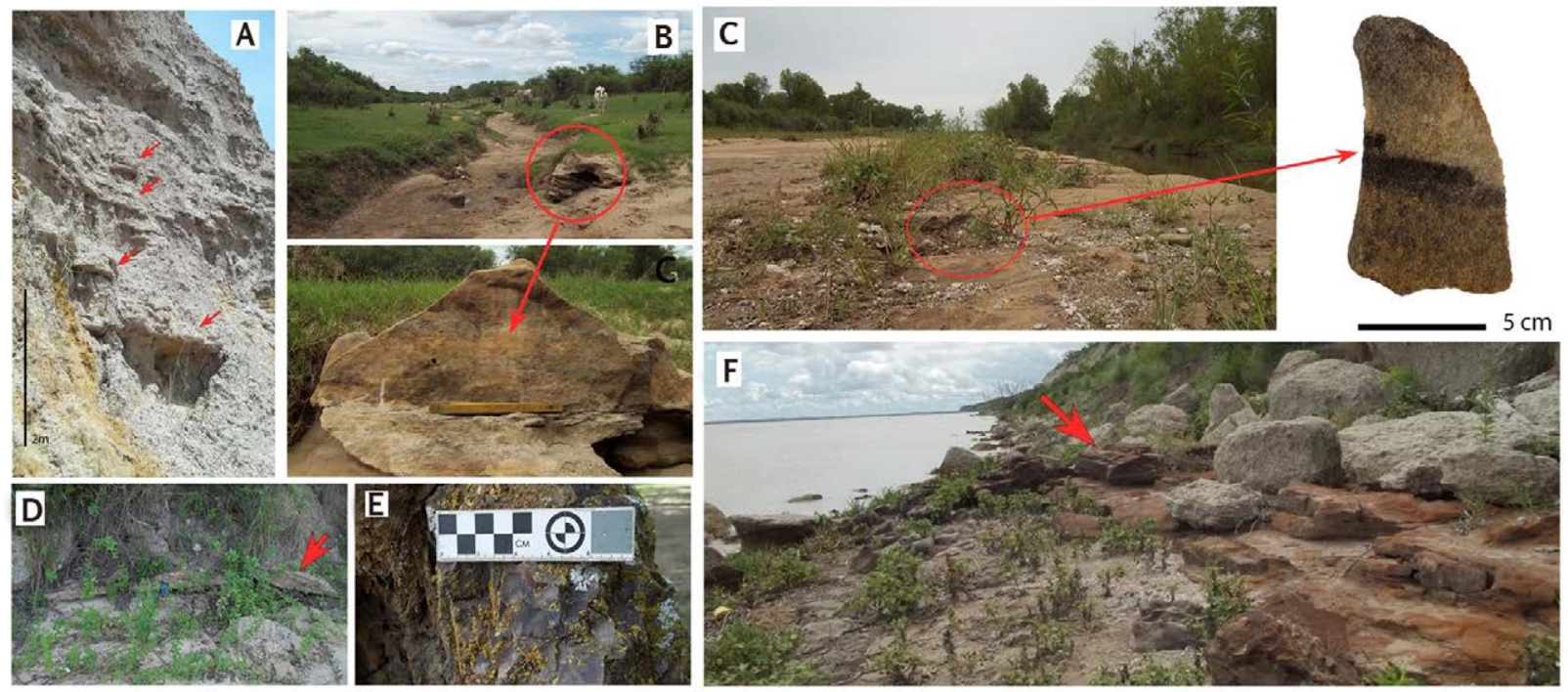

Figura 3. Afloramientos correspondientes a la Fm. Ituzaingó.

y cemento carbonático. Estas areniscas se presentan en capas con estratificación entrecruzada de 10 a $20 \mathrm{~cm}$ de espesor, intercaladas con niveles de arenas sueltas (Figura 3A). En la localidad 7 se identificaron areniscas semejantes a las de la localidad 6 , pero con estratificación horizontal y una mejor consolidación. Estas afloran a lo largo del lecho del arroyo Carmona y son accesibles en momentos en que el nivel del agua se encuentra bajo (Figura 3B). En las localidades 8 y 9 se muestrearon areniscas de varias tonalidades (translúcidas, rojizas, negras y amarillentas) que presentaban cementación silícea, tamaño de grano fino y diferentes grados de litificación. Estas rocas exhiben una mejor calidad para la talla que las anteriores ya que poseen gran tenacidad, un esqueleto de tamaño fino y buena fractura concoidea. Las muestras recuperadas sobre los perfiles del río Paraná (localidad 8) se presentan en estratos continuos de poco espesor dispersos a lo largo del perfil. Los niveles superiores son aquellos que presentan cementación silícea y mejor aptitud para la talla. En el arroyo Curtiembre al sur de la localidad homónima (localidad 9) estos niveles de areniscas se presentan tanto en el lecho del arroyo como en parte de sus barrancas (Figura 3C, véase detalle de arenisca). En las localidades 10 y 11 se registraron areniscas masivas dispuestas de modo discontinuo sobre los perfiles de los cursos de agua. Presentan colores blanquecinos y amarillentos, cementos carbónaticos, tamaños de grano medianos a gruesos y mala calidad para la talla (Figura 3D).

En todas las localidades de la Formación Ituzaingó (localidades 6 a 11) se pudieron observar restos vegetales silicificados (xilópalos) (Figura 3E). Estos cherts presentan una gran variabilidad en sus aptitudes para la talla en función de la cantidad de impurezas y grado de silicificación. Si bien los xilópalos de mejor calidad pudieron ser fuentes de materias primas líticas relativamente importantes - y de hecho han sido registradas en sitios del sur de Entre Ríos (Apolinaire, 2017) - se trata de un recurso limitado, fácilmente agotable y escasamente previsible, en tanto que su hallazgo es fortuito.

En la localidad 12 se registraron areniscas semejantes a las observadas en las localidades 10 y 11, así como también niveles de arenas ocráceas con elevado contenido de hierro (Figura 3F). Parte de estos niveles se encuentran diagenizados, formando areniscas de grano medio a grueso con cemento ferruginoso. La utilidad de esta última variedad de arenisca es escasa para la manufactura de herramientas, aunque sí pudieron ser una importante fuente de minerales colorantes. 

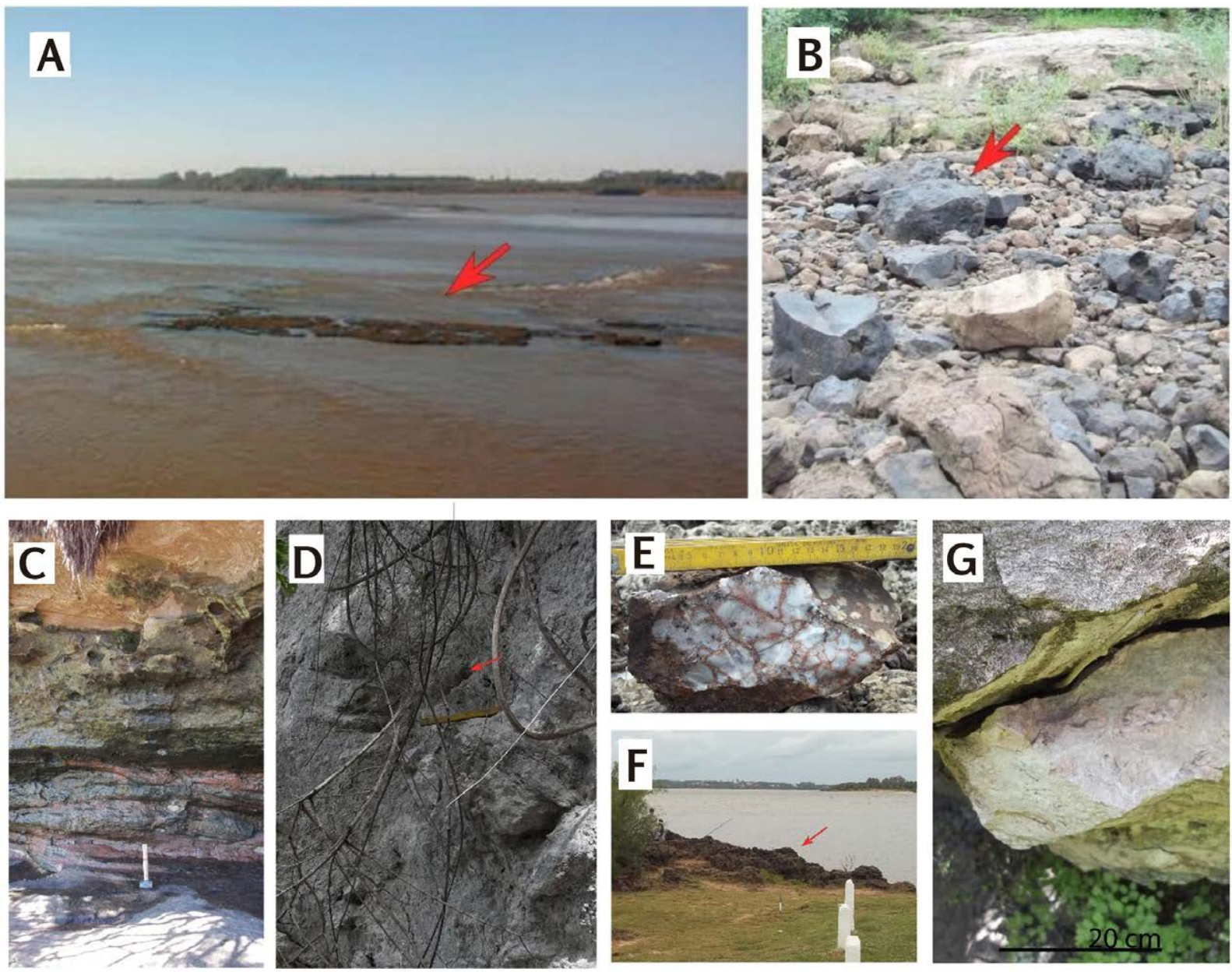

Figura 4. Afloramientos correspondientes a la Fm. Serra Geral y Fm. Yeruá.

La localidad 13 se ubica sobre el arroyo La Jacinta, afluente del río Gualeguay. Allí se registraron afloramientos discontinuos de arenisca a lo largo del lecho del arroyo. Estas rocas presentan en general una buena calidad para la talla debido a su cemento silíceo y tamaño de grano mediano a fino, aunque ocasionalmente pueden tener dentro de su matriz pequeños rodados de tamaño sábulo. Exhiben estratificación horizontal y colores amarillentos a blanquecinos.

Los afloramientos muestreados de la Fm. Serra Geral se ubican en el departamento Concordia y corresponden a rocas del lecho del río Uruguay que conforman los llamados "saltos". Las localidades 14 y 15 corresponden al Salto Chico y al "salto" de Paso Hervidero (Figura 4A). En ambos casos se registraron basaltos masivos, sin vesículas silíceas, de tonos rojizos a negruzcos, gran tenacidad y una regular calidad para la talla. Cabe destacar que grandes bloques de basalto son transportados por el río a poca distancia de estos afloramientos, constituyendo depósitos secundarios de muy fácil acceso en las playas adyacentes a los saltos (Figura 4B).

La formación Puerto Yeruá comprende una amplia variedad de litologías y posee afloramientos a lo largo de los departamentos Colón y Concordia. La localidad 16 corresponde a un perfil de areniscas rojizas (Figura 4C). Sobre la base de este perfil se reconocen areniscas de grano grueso, poco consolidadas y con estratificación entrecruzada. Sobre estas apoyan areniscas masivas mal seleccionadas y poco consolidadas que presentan algunos lentes silicificados. El perfil remata en areniscas 
rojizo-amarillentas, mejor consolidadas que en los niveles inferiores, de grano grueso y estratificación horizontal. Es interesante destacar que, aun entre las areniscas mejor litificadas, las calidades para la talla de estas rocas son regulares a malas. Sin embargo, las variedades consolidadas, debido a su tenacidad y tamaño de grano grueso, brindan buenas superficies abrasivas y constituyen por lo tanto una materia prima apta para su utilización en artefactos de molienda.

Las localidades 17 y 18 corresponden a las barrancas del Uruguay al norte y al sur de la vieja calera Barquín, respectivamente. Cabe destacar que en estas localidades no se recuperaron muestras de mano y la caracterización de las rocas se realizó in situ. Dentro de los perfiles de las barrancas del río se reconoce un paquete carbonático que presenta nódulos de chert silíceo de diferentes tamaños y tonalidades grisáceas a translúcidas (Figura 4D). Estos nódulos presentan calidades para la talla variables, desde muy buenas a regulares y malas, en función de la presencia de cavidades e impurezas. Debajo de estos carbonatos se desarrollan capas de aspecto brechoso compuestas por cherts (calizas silicificadas) de diferentes tonalidades (blancas y anaranjadas), unidos por venillas de areniscas silicificadas muy finas de color rojo. Niveles semejantes a estos últimos, pero de tonos más rojizos, pueden encontrarse en la localidad 19, al sur de la ciudad de Colón (Figura 4E y F). Por último, dentro de la formación Puerto Yeruá, se incluyen también calizas carbonáticas con diferente nivel de consolidación. En la localidad 20 se encuentran extensos afloramientos de estas rocas (Figura 4G), que en algunos casos presentan pequeños nódulos de sílice incluidos en su matriz. La utilidad de estas calizas para la manufactura de artefactos es discutible pero, la presencia de algunas variedades muy tenaces, lleva a no descartar su potencial utilidad.

Los afloramientos relevados correspondientes a la Fm. Salto Chico se distribuyen en los departamentos Uruguay, Colón y Concordia. La localidad 21 se encuentra sobre las barrancas del río Uruguay y presenta afloramientos de areniscas con estratificación horizontal (Figura 5A), bien consolidadas, de grano fino, cemento silíceo y tonalidades amarillentas y rojizas. Los niveles de arenisca se presentan en la parte superior de la barranca y se intercalan con niveles de limos, arenas y rodados fluviales (Figura 5B). En la localidad 22, en las inmediaciones de la ciudad de Puerto Yeruá, se identificaron areniscas silicificadas con tamaños de grano medio y tonalidades rojizas (Figura 5C). Estas se disponen intercaladas con niveles de arenas, arenas ocráceas y gravas. En ambas localidades las areniscas presentan buena calidad para la talla.

En la localidad 23 se muestreó un afloramiento del Ao. San Antonio donde se identificaron areniscas amarillentas (Figura 6A y B) y verdosas masivas, con un tamaño de grano que grada de muy fino en los niveles inferiores a fino en los superiores. El cemento silíceo y la buena selección de su esqueleto (Figura 6C) brindan a estas rocas una gran tenacidad y excelente aptitud para la talla. Las areniscas de la localidad 24 presentan características semejantes, aunque poseen un tamaño de grano mayor (Figura 7). Las localidades 25 y 26 presentan areniscas amarillentas masivas con tamaños de grano medianos a finos y buena calidad para la talla.

Por último, es interesante señalar que entre las arenas de la formación Salto Chico se encuentran numerosos leños fósiles silicificados que, al igual que en el caso de la Fm. Ituzaingó, presentan tamaños y grados de silicificación variables. Estos xilópalos se presentan recurrentemente asociados a los sectores y niveles que presentan areniscas silicificadas y pueden incluso encontrarse incorporados dentro de ellas.

\section{Petrografía microscópica de las areniscas}

En la Tabla 2 se sintetizan las características petrográficas de las láminas delgadas analizadas. Las muestras corresponden a rocas epiclásticas sedimentarias compuestas 

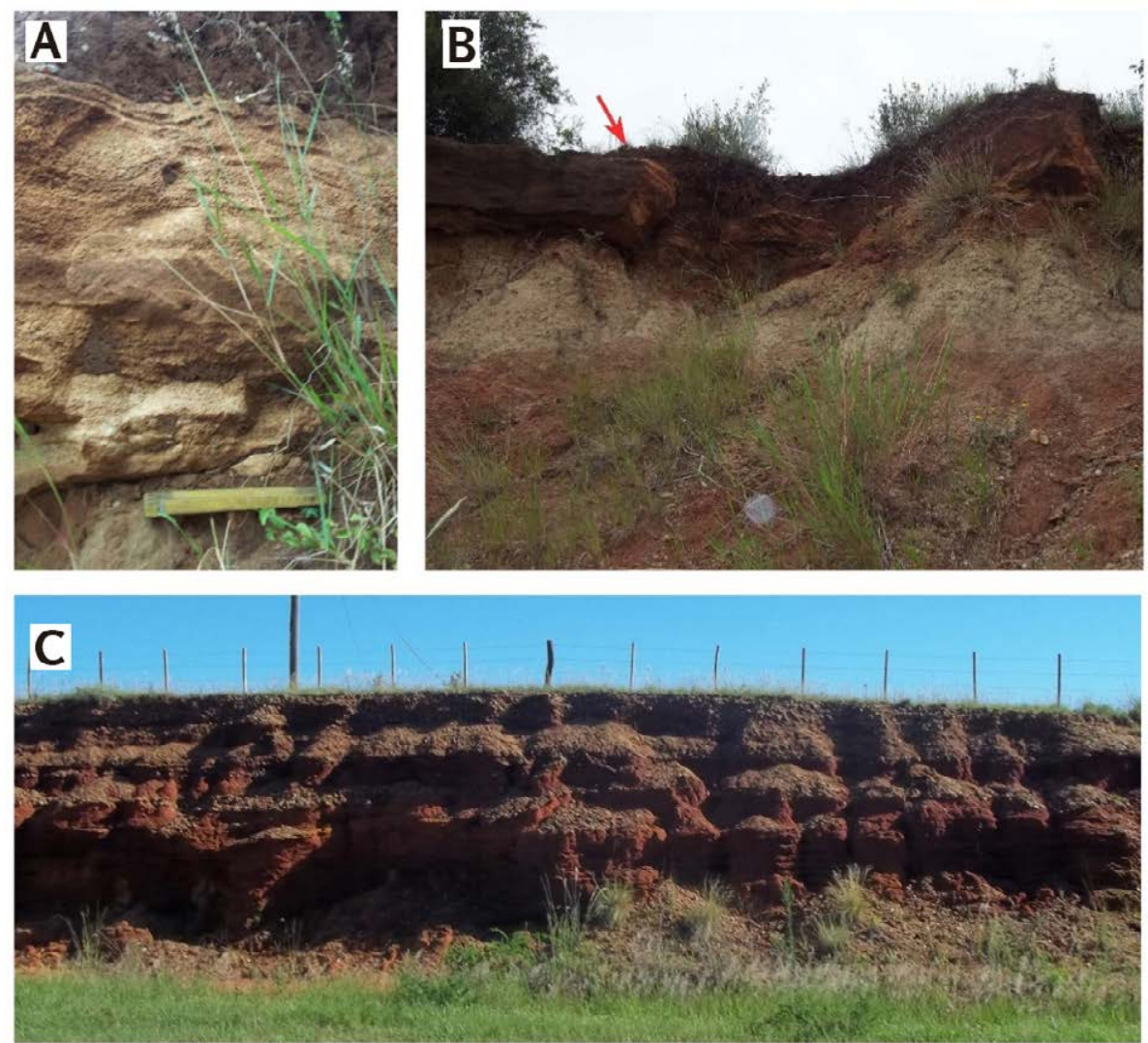

Figura 5. Afloramientos correspondientes a la Fm. Salto Chico.
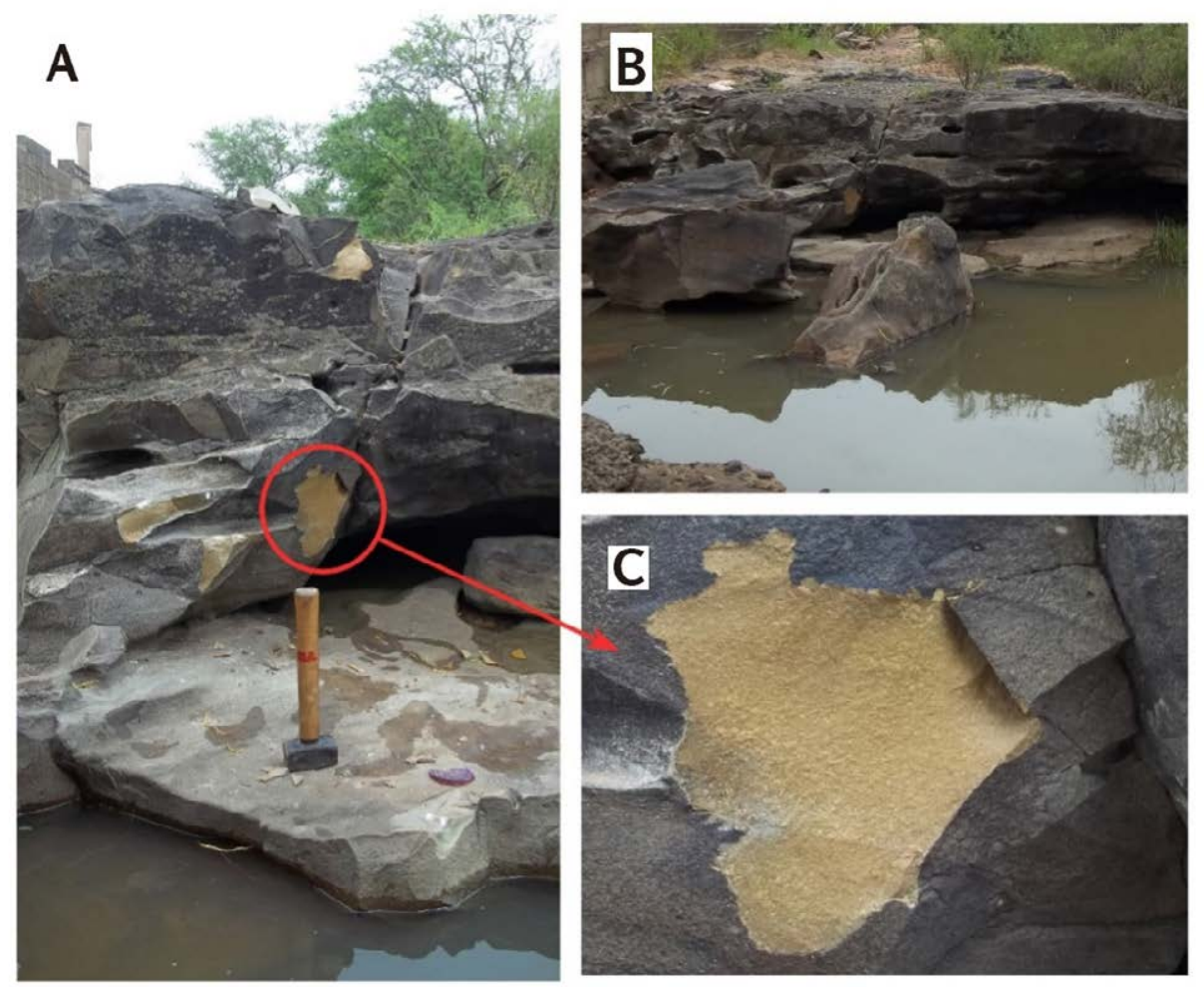

Figura 6. Afloramientos correspondientes a la Fm. Salto Chico. 

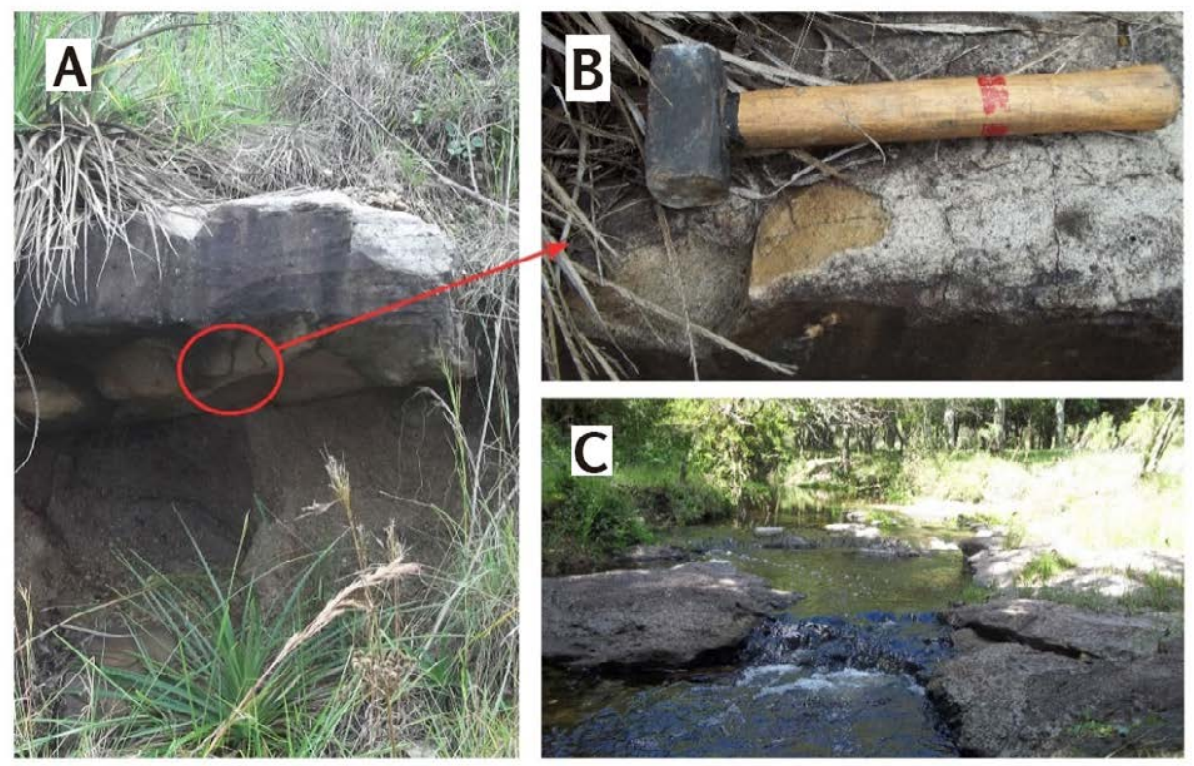

Figura 7. Afloramientos correspondientes a la Fm. Salto Chico.

principalmente por clastos de cuarzo, en porcentajes que varían entre $86,7 \%$ a 97,5\%. Las muestras procedentes de la Fm. Paraná presentan porcentajes relativamente elevados de feldespatos (> 5\%), lo que permitió clasificarlas como subarcosas. En cambio, estos valores son bajos para las muestras correspondientes a las formaciones Ituzaingó y Salto Chico. En las primeras se registraron proporciones de clastos líticos entre $9 \%$ y $2,5 \%$, por lo que se clasificaron como sublitoarenitas, mientras que en la mayoría de las muestras de Salto Chico los porcentajes tanto de clastos líticos como de feldespatos son bajos, por lo que corresponden en su mayoría a cuarzoarenitas. Por otra parte, el cemento está compuesto por calcita en las muestras de la Fm. Paraná y distintas variantes de sílice en las muestras de la Fm. Salto Chico, mientras que se registraron ambos tipos de cemento en los cortes de la Fm. Ituzaingó. En las muestras con cemento silíceo las proporciones de cemento varían entre 37\% y 62\%. Las muestras UL11-M1 y PL13-M1 son las que menor porcentaje presentan (menor a 40\%) y corresponden principalmente a cementos compuestos por ópalo. Las muestras UL8-M1 y UL8-M2, UL11-M2, UL10-M1 son las de mayores porcentajes (superiores a 60\%). Las restantes muestras presentan entre un $40 \%$ y un $60 \%$ de cemento.

En cuanto a la textura, las muestras de las formaciones Ituzaingó y Salto Chico presentan en su mayoría un tamaño de grano correspondiente a arena fina, mientras que en las muestras de la Fm. Paraná se registran tamaños menores, entre limo y arena muy fina. La morfología de los clastos varía entre angulosa a redondeada, tendiendo a una mayor angulosidad en las muestras de la Fm Paraná. La selección varía entre moderada y muy buena, el empaquetamiento es mayormente de tipo cemento sostén y se registra escasa o nula porosidad y matriz en todos los casos.

Las muestras arqueológicas procedentes del sitio Laguna del Negro 1 (LDN1), ubicado en las llanuras interiores entrerrianas (departamento Gualeguay), corresponden a artefactos elaborados tanto por talla como por picado, pulido y abrasión y presentan en dos casos evidencias macroscópicas de termoalteración (Apolinaire, 2017). Teniendo en cuenta su composición, corresponden a cuarzoarenitas o sublitoarenitas. Desde el punto de vista textural, el esqueleto se compone de clastos de morfología redondeada a subredondeada, de tamaño arena fina o media y con una buena a moderada selección 


\begin{tabular}{|c|c|c|c|c|c|c|c|c|c|c|c|c|c|}
\hline 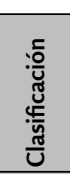 & & 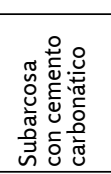 & 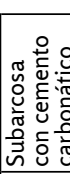 & 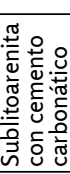 & 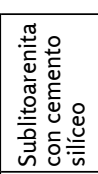 & 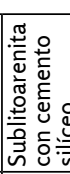 & 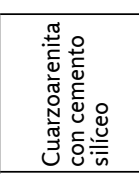 & 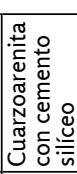 & 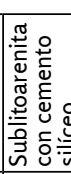 & 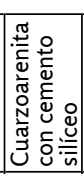 & 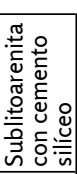 & 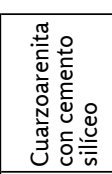 & 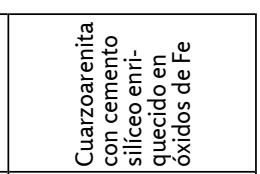 \\
\hline 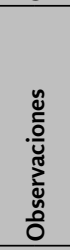 & & & & & 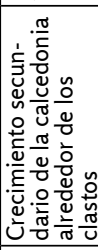 & 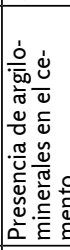 & 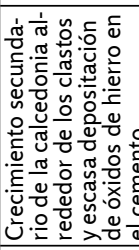 & 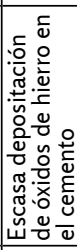 & & & & 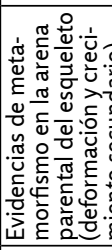 & 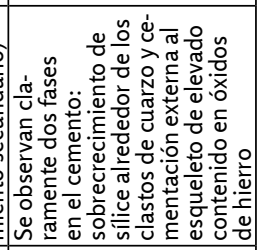 \\
\hline \multirow[b]{6}{*}{ } & 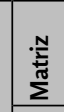 & 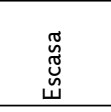 & 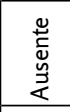 & 总 & 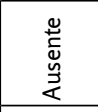 & 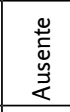 & 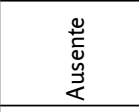 & 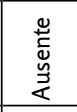 & 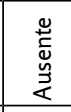 & 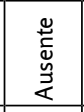 & 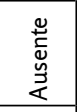 & 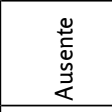 & 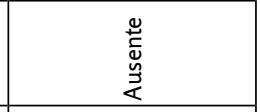 \\
\hline & 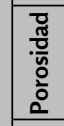 & 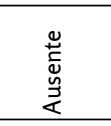 & 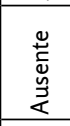 & 总 & 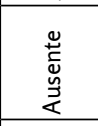 & $\begin{array}{l}\widetilde{心} \\
\text { 岀 } \\
\end{array}$ & 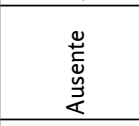 & 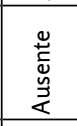 & 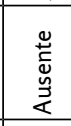 & 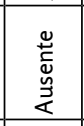 & 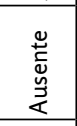 & 节 & 苂 \\
\hline & 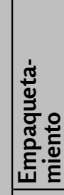 & 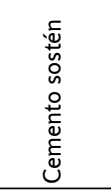 & 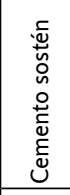 & 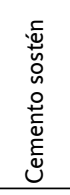 & 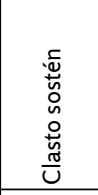 & 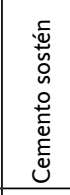 & 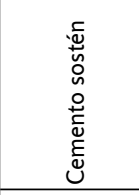 & 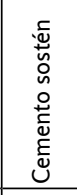 & 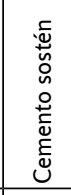 & 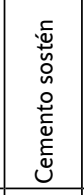 & 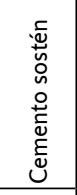 & 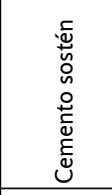 & 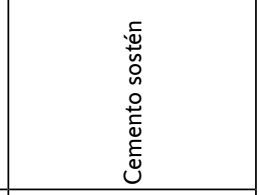 \\
\hline & 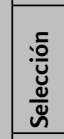 & 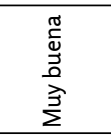 & 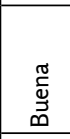 & $\begin{array}{l}\frac{\pi}{0} \\
\frac{\pi}{0} \\
\frac{\pi}{0} \\
\Sigma \\
\end{array}$ & 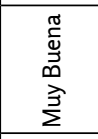 & 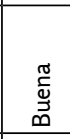 & 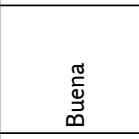 & 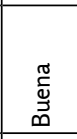 & 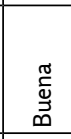 & 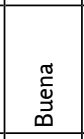 & 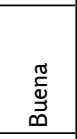 & 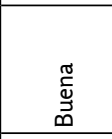 & 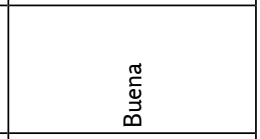 \\
\hline & 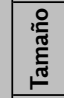 & 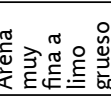 & 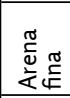 & 芴 & 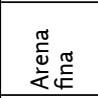 & 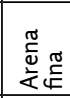 & 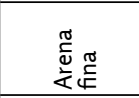 & 䲶 & 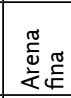 & 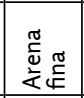 & 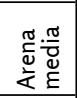 & 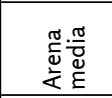 & 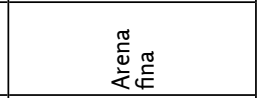 \\
\hline & $\begin{array}{l}\frac{\pi}{0} \\
\frac{0}{00} \\
\frac{0}{0} \\
\frac{0}{2} \\
\end{array}$ & 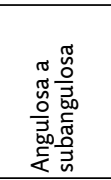 & 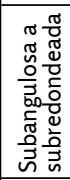 & 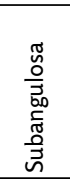 & 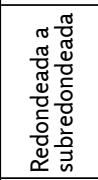 & 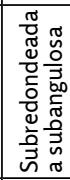 & 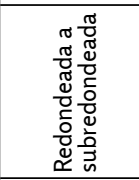 & 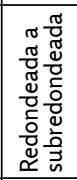 & 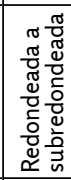 & 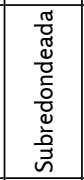 & 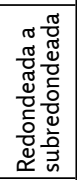 & 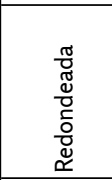 & 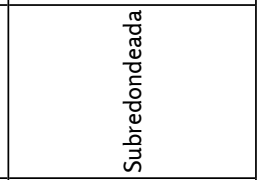 \\
\hline \multirow{6}{*}{ 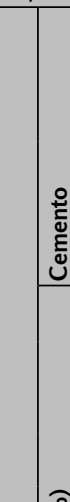 } & $\mid$ & & & 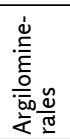 & $\begin{array}{l}\frac{0}{\pi 0} \\
.0 \\
.0\end{array}$ & 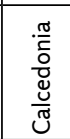 & $\begin{array}{l}\frac{0}{\pi ٍ} \\
.0\end{array}$ & & 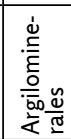 & & & 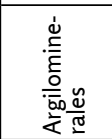 & 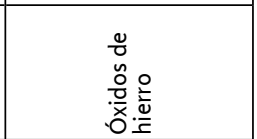 \\
\hline & 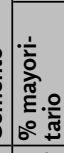 & $\frac{\frac{\pi}{5}}{\frac{\pi}{\tilde{J}}}$ & $\frac{\sqrt[\pi]{\tilde{U}}}{\frac{\mathrm{U}}{\mathrm{J}}}$ & $\frac{\mathbb{\pi}}{\frac{\pi}{\pi}}$ & 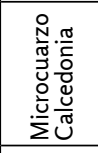 & $\begin{array}{l}\frac{0}{\pi} \\
\frac{\pi}{0}\end{array}$ & 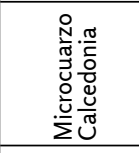 & 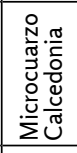 & 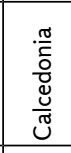 & 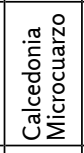 & $\begin{array}{l}\frac{0}{\pi / 0} \\
\text { ○. }\end{array}$ & $\frac{0}{\pi} \frac{0}{0}$ & 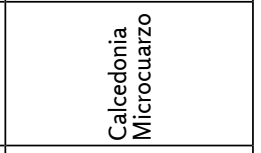 \\
\hline & $\sum_{\Sigma}^{\pi}$ & o & $\hat{0}$ & 1 & & & 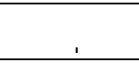 & & & 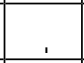 & & & 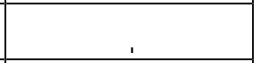 \\
\hline & $\breve{u}$ & $\hbar$ & $\stackrel{n}{n}$ & 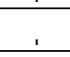 & oे & $\begin{array}{c}\infty \\
\infty \\
0 \\
0\end{array}$ & & - & - & 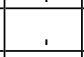 & . & 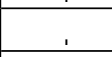 & . \\
\hline & $\underline{x}$ & $\hat{i}$ & 1 & $\hat{0}$ & 1 & $\begin{array}{l}t \\
0 \\
0\end{array}$ & $0^{n}$ & $\begin{array}{l}t \\
0\end{array}$ & $o^{m}$ &. & , & ב̃ & . \\
\hline & 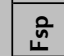 & 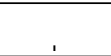 & 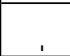 & $\stackrel{H}{\Psi}$ & 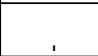 & St & $\hat{0}$ & $0_{0}^{t}$ & $\begin{array}{l}0 \\
0 \\
0\end{array}$ & 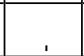 & 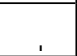 & . & $\hat{f}$ \\
\hline 巳 & \pm &. & $\tilde{o}$ & $\stackrel{\infty}{m}$ & $\hat{i}$ & $a$ & $\hat{i}$ & $\hat{f}$ & $\hat{i}$ & $\hat{o}$ & $\tilde{w}$ & $\stackrel{m}{i}$ & $H$ \\
\hline \multirow{2}{*}{ 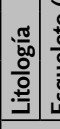 } & उु &. & - & $\tilde{m}$ & $\hat{i}$ & $\hat{i}$ & I & $\sqrt[N]{4}$ & i & $m$ & 于 & o & I \\
\hline & & $\sigma$ & ๙ే & $a$ & ప & $\begin{array}{l}\widehat{0} \\
\infty\end{array}$ & $\alpha$ & 志 & 告 & ட & $n$ & 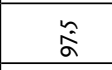 & 홍 \\
\hline 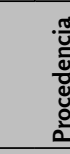 & & 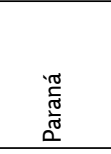 & 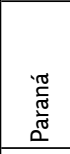 & 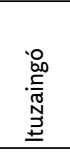 & 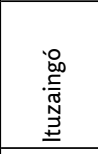 & $\begin{array}{l}\text { 品 } \\
\text {. } \\
\text { N } \\
\text { İ } \\
\end{array}$ & 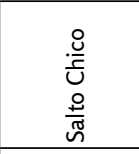 & 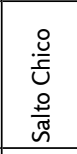 & 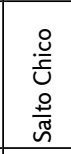 & 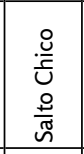 & 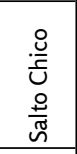 & 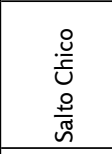 & 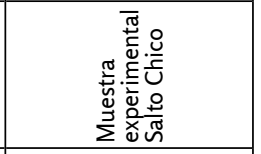 \\
\hline 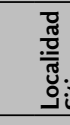 & & $m$ & $\sigma$ & 6 & $a$ & $\cong$ & $\vec{N}$ & $\overrightarrow{4}$ & N & $\tilde{N}$ & A & A & $\tilde{x}$ \\
\hline$\frac{\sqrt{5}}{4}$ & & 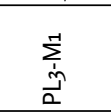 & $\sum_{\substack{j \\
\Lambda}}^{+}$ & $\sum_{\substack{0 \\
0}}^{+1}$ & $\sum_{\dot{\alpha}}^{n}$ & $\sum_{i=j}^{+1}$ & $\sum_{\substack{+\infty}}^{+}$ & $\sum_{\infty}^{N}$ & $\sum_{\dot{S}}^{+1}$ & $\begin{array}{l}\sum_{0}^{N} \\
\vdots \\
\\
\end{array}$ & $\sum_{j}^{+}$ & $\sum_{i=1}^{N}$ & $\begin{array}{l}\vec{H} \\
\stackrel{\vec{j}}{J}\end{array}$ \\
\hline
\end{tabular}

Tabla 2. Petrografía microscópica de las muestras de roca naturales, experimentales y arqueológicas. Referencias: Qtz: Cuarzo, Cal: Calcedonia, Lt: Líticos, Fp: Feldespatos potásicos, Px: Piroxeno, Fc: Feldespatos calcosódicos, Mca: Micas. 


\begin{tabular}{|c|c|c|c|c|c|c|c|c|c|c|c|}
\hline 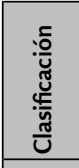 & & 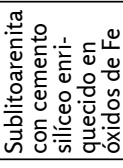 & 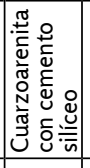 & 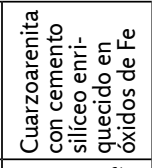 & 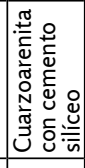 & 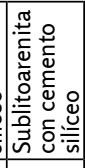 & 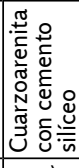 & 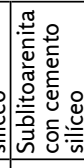 & 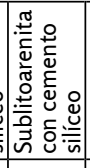 & 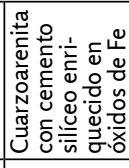 & 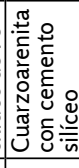 \\
\hline 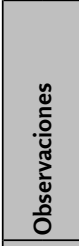 & & 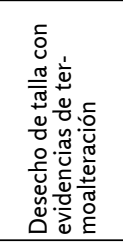 & 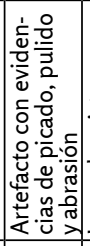 & 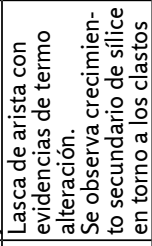 & 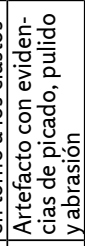 & 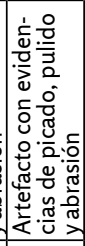 & 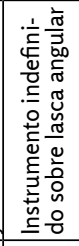 & 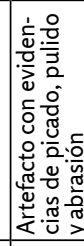 & 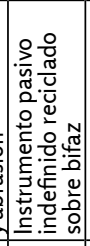 & 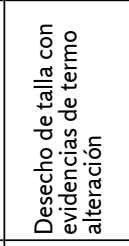 & 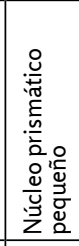 \\
\hline \multirow[b]{6}{*}{ 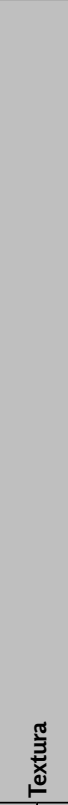 } & $\begin{array}{l}N \\
\stackrel{N}{\Sigma} \\
\sum\end{array}$ & 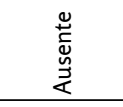 & 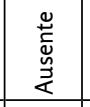 & 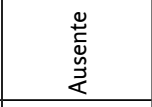 & 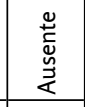 & 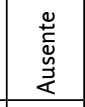 & 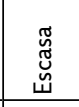 & 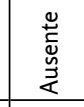 & 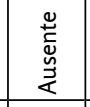 & 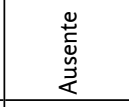 & 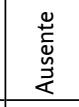 \\
\hline & 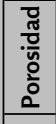 & 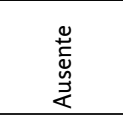 & 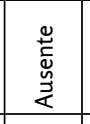 & 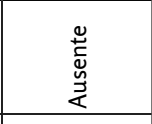 & 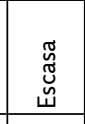 & 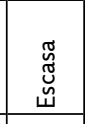 & 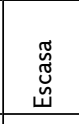 & 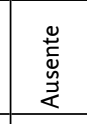 & 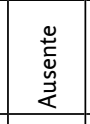 & 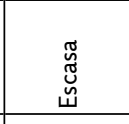 & 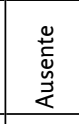 \\
\hline & 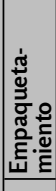 & 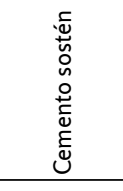 & 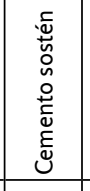 & 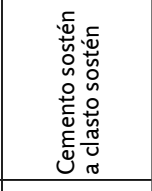 & 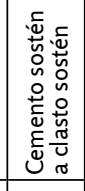 & 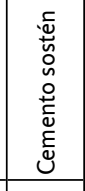 & 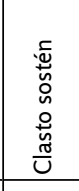 & 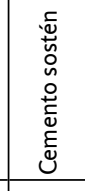 & 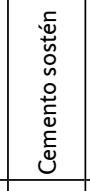 & 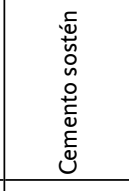 & 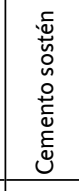 \\
\hline & 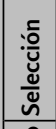 & 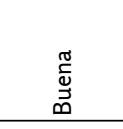 & $\begin{array}{l}\frac{\pi}{\pi} \\
\frac{\pi}{2} \\
\frac{\pi}{0} \\
\Sigma \\
\end{array}$ & 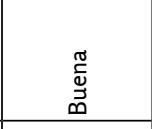 & 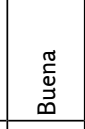 & $\stackrel{\widetilde{̃}}{\tilde{\Xi}}$ & $\begin{array}{l}\frac{\pi}{0} \\
\frac{\pi}{\pi} \\
\frac{\pi}{0} \\
\Sigma \\
\end{array}$ & 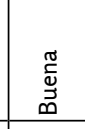 & $\begin{array}{l}\frac{\pi}{\pi} \\
\frac{\pi}{2} \\
\frac{\pi}{0} \\
\Sigma \\
\end{array}$ & 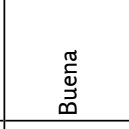 & 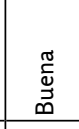 \\
\hline & 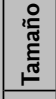 & 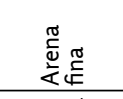 & 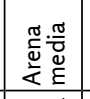 & 蛋 & 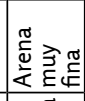 & 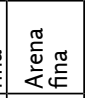 & 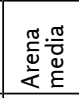 & 总 & 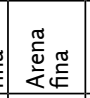 & 苞芒 & 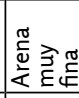 \\
\hline & $\begin{array}{l}\frac{\pi}{60} \\
\frac{0}{0} \\
\frac{1}{0} \\
\frac{0}{2}\end{array}$ & 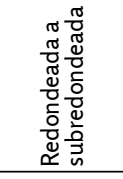 & 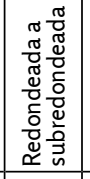 & 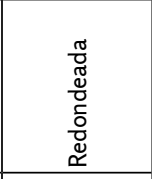 & 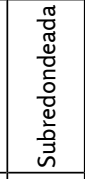 & 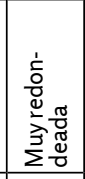 & 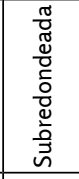 & 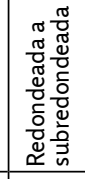 & 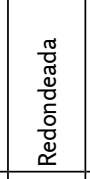 & 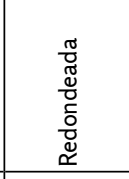 & 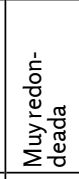 \\
\hline \multirow{9}{*}{ 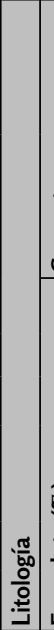 } & 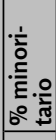 & 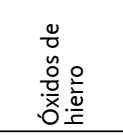 & & 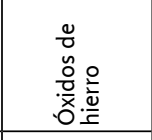 & 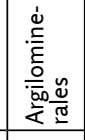 & 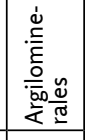 & 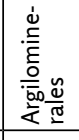 & & $\begin{array}{l}\frac{0}{\pi} \\
.00\end{array}$ & 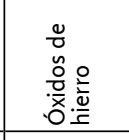 & \\
\hline & 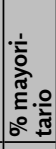 & 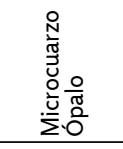 & 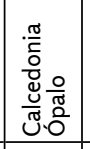 & 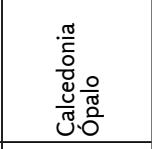 & 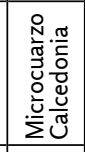 & 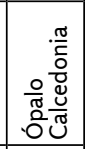 & 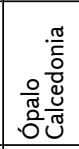 & $\begin{array}{l}\frac{0}{\pi} \\
.0 \\
0\end{array}$ & 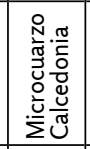 & 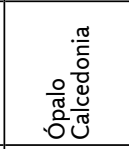 & 을 $\frac{. \frac{\pi}{\sigma}}{\frac{0}{0}}$ \\
\hline & 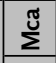 & & & & & & & & & & \\
\hline & u & , & . & $\tilde{c}^{1}$ & . & & $\begin{array}{l}0 \\
0 \\
0\end{array}$ & $\stackrel{m}{i}$ &. & & I \\
\hline & $\underline{x}$ & . & & $\tilde{O}_{0}^{N}$ & & & & & $\underset{\sim}{\sim}$ & & \\
\hline & ผิ & $\hat{0}$ & $0^{2}$ & & $\hat{0}$ & & & $\begin{array}{l}0 \\
0 \\
0\end{array}$ & $\stackrel{m}{r}$ & $\hat{0}$ & \\
\hline & \pm & $\hat{i}$ & $\hat{0}$ & $\begin{array}{l}\infty \\
0 \\
0\end{array}$ & $\tilde{N}$ & $\stackrel{+}{N}$ & $\underset{\sim}{N}$ & $\Sigma$ & $\hat{i}$ & $\hat{0}$ & $\vec{N}$ \\
\hline & ] & $\hat{i}$ & $\stackrel{+}{A}$ & 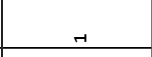 & $\hat{m}$ & $\hat{\alpha}$ & $\underset{+\rightarrow}{\infty}$ & $\begin{array}{l}0 \\
\text { i }\end{array}$ & 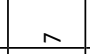 & & $\stackrel{+}{-}$ \\
\hline & 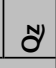 & ๙̊ & $\stackrel{ \pm}{\alpha}$ & $\begin{array}{l}6 \\
6 \\
\swarrow\end{array}$ & పू & $\begin{array}{l}\infty \\
\infty \\
\infty\end{array}$ & పू & å & $\begin{array}{l}\infty \\
\infty \\
\infty\end{array}$ & $\hat{\alpha}$ & పू \\
\hline \multicolumn{2}{|c|}{ 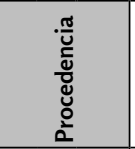 } & 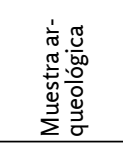 & 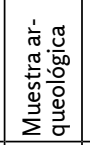 & 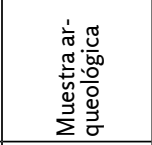 & 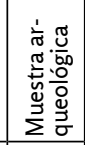 & 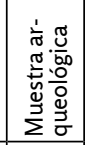 & 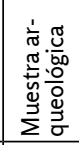 & 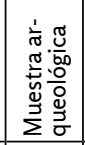 & 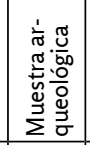 & 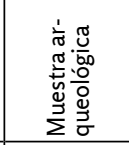 & 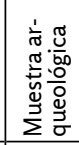 \\
\hline \multicolumn{2}{|c|}{ 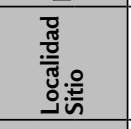 } & 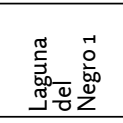 & 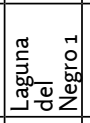 & 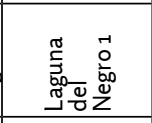 & 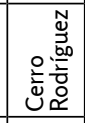 & 온. & 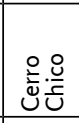 & 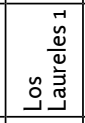 & 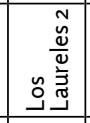 & 气 & 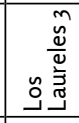 \\
\hline \multicolumn{2}{|c|}{ 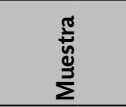 } & 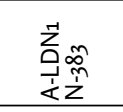 & 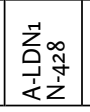 & 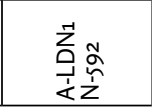 & 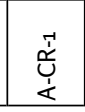 & $\begin{array}{l}\vec{I} \\
\dot{U} \\
\dot{1} \\
\end{array}$ & 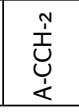 & 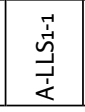 & $\underset{\stackrel{N}{N}}{\stackrel{N}{*}}$ & 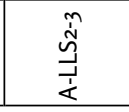 & 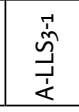 \\
\hline
\end{tabular}

Tabla 2. Petrografía microscópica de las muestras de roca naturales, experimentales y arqueológicas. Referencias.Qtz: Cuarzo, Cal: Calcedonia, Lt: Líticos, Fp: Feldespatos potásicos, Px: Piroxeno, Fc: Feldespatos calcosódicos, Mca: Micas. 
de tamaño. Estos clastos se encuentran empaquetados con cemento silíceo, el cual se encuentra enriquecido en óxidos de hierro en las muestras termoalteradas. Las muestras arqueológicas procedentes del Delta Superior del Paraná corresponden a los sitios Cero Chico, Cerro Rodríguez y Los Laureles 1, 2 y 3. Presentan rasgos composicionales y texturales similares a las anteriores y pueden caracterizarse como cuarzoarenitas o sublitoarenitas con cemento silíceo, cuyas arenas parentales presentan granulometría fina a muy fina y elevada madurez.

\section{Muestras experimentales}

Las muestras de la Fm. Salto Chico e Ituzaingó termoalteradas experimentalmente exhiben cambios macroscópicos en su color, brillo y tenacidad. Las tonalidades cambian rápidamente con la temperatura de blanquecinas o amarillentas a rojizas y el brillo pasa de vítreo a graso. Además, las rocas se vuelven altamente friables y pueden presentar microfracturas en su superficie. En cambio, la muestra de la Fm. Paraná no adquirió tonalidades rojizas sino grisáceas y no se registraron en este caso cambios en la tenacidad.

La muestra de la Fm. Salto Chico que fue analizada microscópicamente corresponde a una cuarzoarenita de cemento silíceo, compuesta por clastos de arena fina y bien seleccionada. El cemento denota una coloración roja producto de un elevado contenido en óxidos de hierro. Es posible observar, con mayor claridad que en la muestra no termoalterada (UL10-M1), dos fases en el cemento: por un lado, el sobrecrecimiento de sílice alrededor de los clastos de cuarzo y, por el otro, una cementación silícea externa a los núcleos de cristalización con un gran contenido de hematita. Cabe destacar que no se observaron evidencias de recristalización de la sílice amorfa y/o la calcedonia en microcuarzo, como sería esperable en casos de elevado estrés térmico (Frranzen et al., 2012; Kompaniková, Gomez-Heras, Michňová, Durmeková y Vlčko, 2014).

\section{Discusión y conclusiones}

\section{Diferenciación de las rocas silicoclásticas y calidad para la manufactura de artefactos líticos}

A partir de los estudios macroscópicos y los análisis de lámina delgada efectuados, es posible delinear algunas tendencias generales que permitan diferenciar petrográficamente las rocas silicoclásticas relevadas en la región. Las principales diferencias se registran entre las rocas silicoclásticas de la Fm. Paraná y las areniscas de las formaciones Ituzaingó y Salto Chico. Las primeras presentan clastos de tamaño limo a arenas medianas, bien seleccionados, con morfología principalmente subangulosa a angulosa y con una frecuencia relativamente elevada de feldespatos, filosilicatos e inosilicatos. Su empaquetamiento está dado principalmente por cemento, el cual es exclusivamente carbonático (calcita). Estas rocas pueden clasificarse como limolitas y areniscas subarcósicas de cemento carbonático. Así, la porción detrítica de las rocas de la Fm. Paraná revela una menor madurez que la evidenciada en las areniscas de las restantes formaciones. En estas últimas se observa una mayor preponderancia de clastos de cuarzo y, en menor medida, fragmentos líticos, clastos de calcedonia y feldespatos. Además, el elevado grado de redondez en la mayoría de las muestras y la escasez de matriz, indican una elevada madurez textural. Por otra parte, en el esqueleto de las rocas de las formaciones Ituzaingó y Salto Chico, y a diferencia de lo registrado en la Fm. Paraná, no se registran clastos con tamaños inferiores a arenas. El empaquetamiento es principalmente cemento sostén y el cemento puede ser tanto carbonático como silíceo. Estas rocas pueden ser clasificadas como sublitoarenitas o cuarzoarenitas, pero en ningún caso se registraron limolitas o subarcosas. 


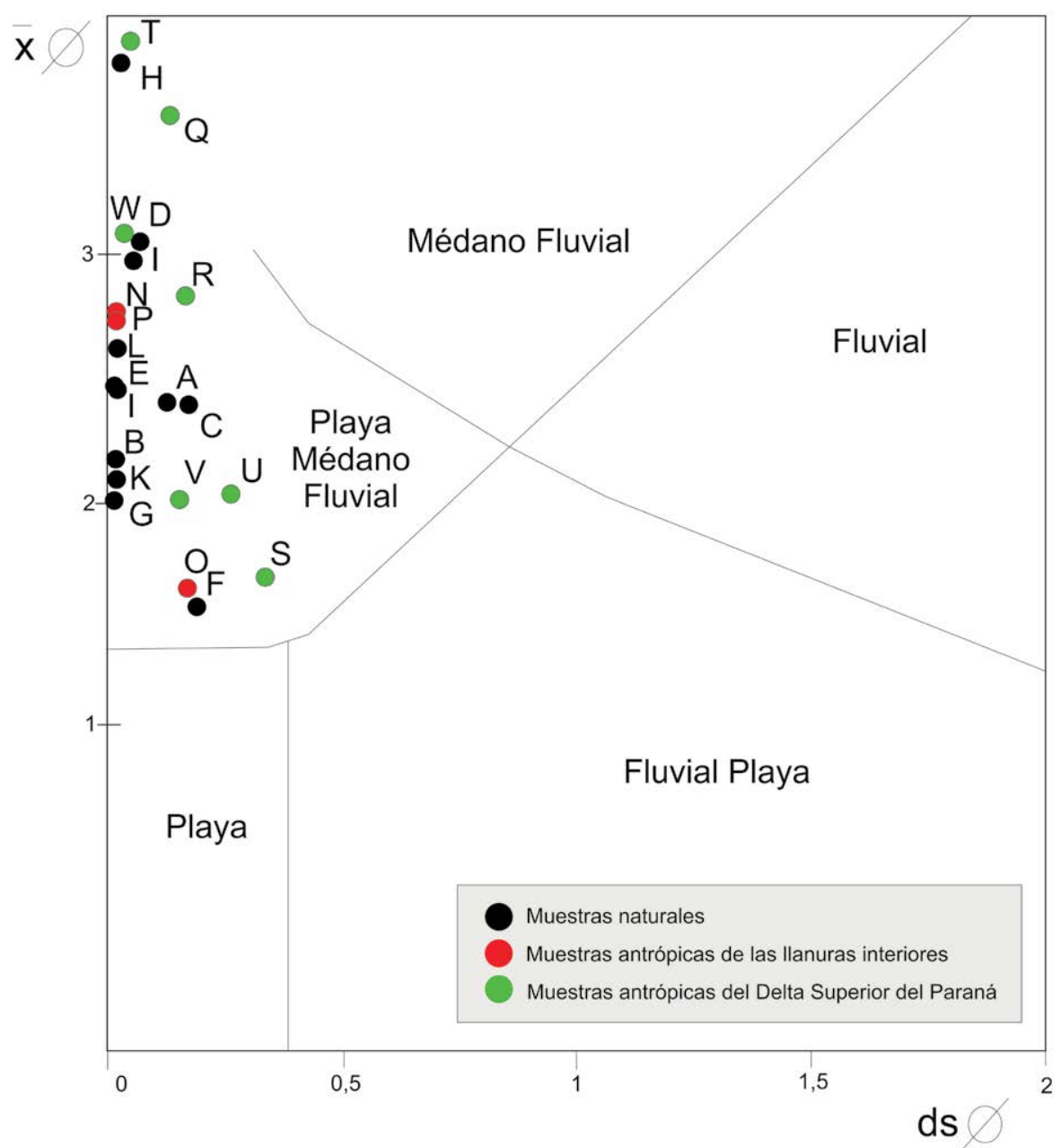

Figura 8. Diagrama de variación media-desvío estándar, modificado de Mazzoni (1977), donde se representa el posible origen de las arenas parentales de las muestras analizadas

En función del análisis granulométrico, las muestras de areniscas analizadas sobre lámina delgada corresponden a arenas que pudieron depositarse ya sea en ambientes eólicos como en ambientes fluviales o de playa (Mazzoni, 1977). Es interesante señalar que las muestras arqueológicas, tanto del Delta Superior del Paraná como de las llanuras interiores presentan una variabilidad semejante a la registrada en las muestras naturales (Figura 8), es decir, ambas presentan valores medios y variaciones de tamaño de grano similares.

Las areniscas con cementos silíceos de las formaciones Ituzaingó y Salto Chico poseen leves diferencias en su composición mineralógica. En líneas generales, las primeras presentan mayores porcentajes de fragmentos líticos incorporados en el esqueleto y en todos los casos corresponden a sublitoarenitas. Sin embargo, Hocsman (2015) analiza láminas delgadas sobre rocas de esta misma formación, registrando cuarzoarenitas, por lo que es posible asumir que existe una mayor variabilidad al interior de esta formación que la que aquí pudo identificarse a partir del muestreo realizado.

Con el fin de observar si existen diferencias significativas en el tamaño de los clastos (eje mayor) entre las muestras de las formaciones Ituzaingó y Salto Chico se llevó a cabo una prueba de ANOVA de un factor. Si bien se observa una leve tendencia a granos de mayor tamaño en las epiclastitas del río Paraná, no se encontraron diferencias 

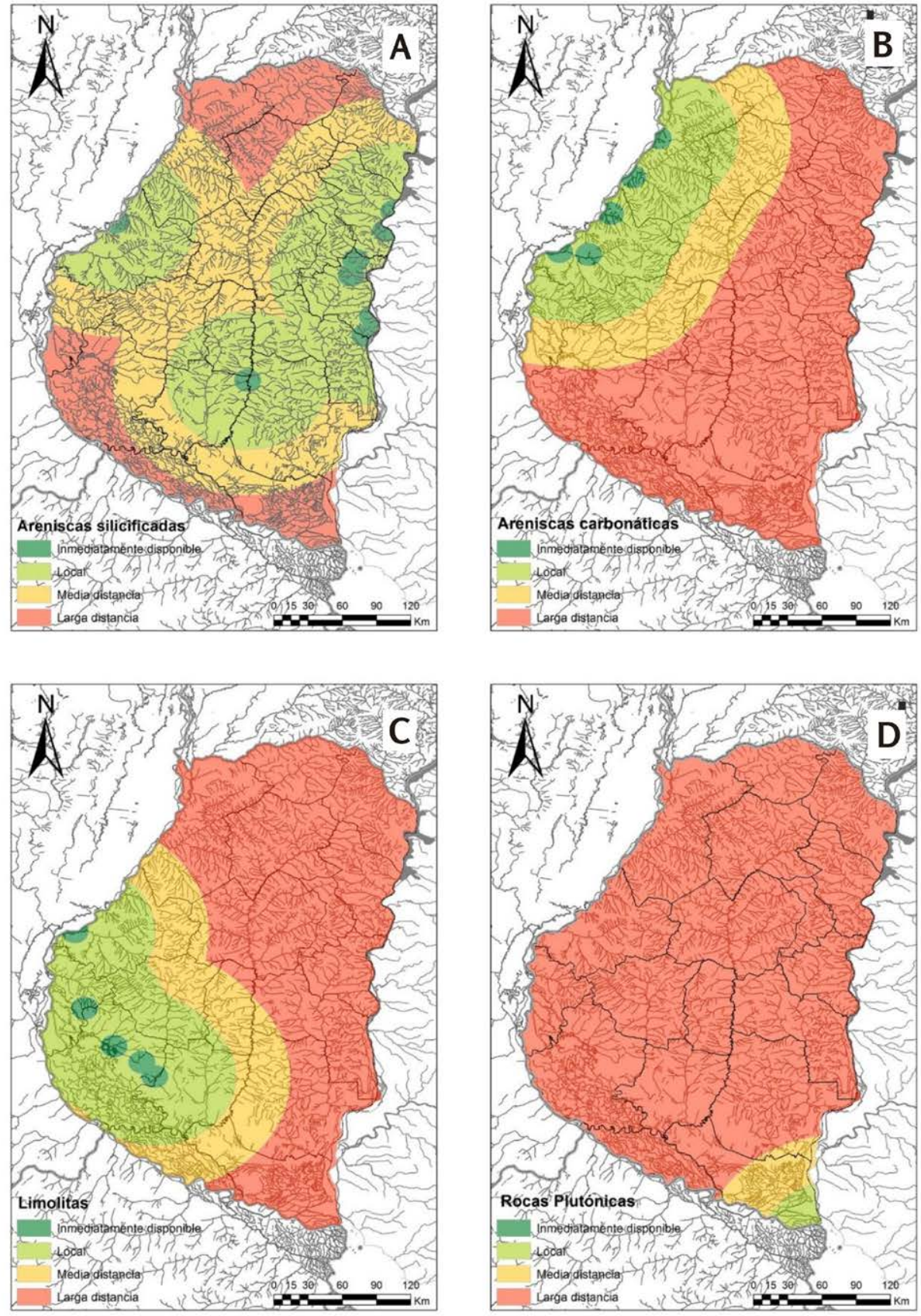

Figura 9. Accesibilidad a los afloramientos primarios de materia prima. A) areniscas silicificadas, B) areniscas carbonáticas, C) limolitas, D) plutónicas y metamorfitas.

significativas entre las dos formaciones $(\mathrm{p} \geq 0,05)$. Mediante un test post-hoc de Tukey se observó que únicamente el subconjunto formado por las muestras UL11-M1 y PL13-M1 presentan una granulometría significativamente mayor a las demás. Estas muestras corresponden tanto a afloramientos de muy buena calidad de la Fm. Salto Chico como a rocas de regular calidad para la talla de la Fm. Ituzaingó. En cuanto a las proporciones de cemento, tampoco se observaron diferencias según la formación geológica de procedencia.

En suma, no es posible diferenciar entre las dos formaciones de areniscas silicificadas (Ituzaingó y Salto Chico) a partir de su composición mineralógica, tamaño de clasto 

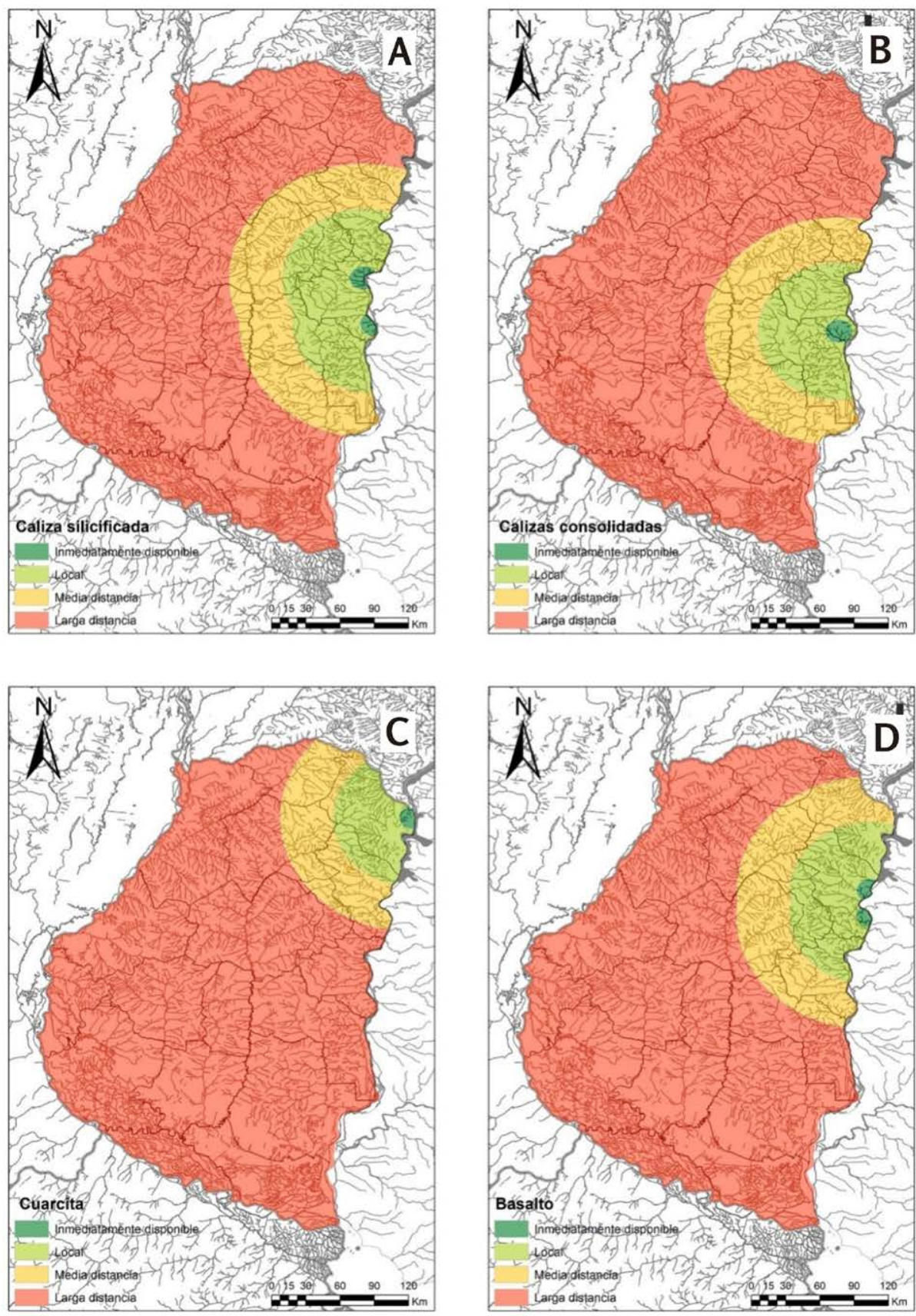

Figura 10. Accesibilidad a los afloramientos primarios de materia prima. A) caliza silicificada, B) calizas consolidadas, C) cuarcita, D) basalto.

o cantidades relativas de cemento. Es decir, la variabilidad registrada para estas características al interior de cada formación es superior a la que puede identificarse entre las formaciones. De hecho, se ha propuesto que ambas son equivalentes y coincidirían lateralmente a la altura del río Gualeguay (Aceñolaza, 2007; Herbst, 2000). Por este motivo, las muestras arqueológicas analizadas, tanto las procedentes del Delta Superior del Paraná como de las llanuras interiores, podrían provenir de cualquiera de estas dos formaciones. Sin embargo, las fuentes de aprovisionamiento más cercanas a los sitios corresponden a los afloramientos de la Fm. Ituzaingó, por lo que es factible suponer que este sea el locus de procedencia de esta materia prima. 
A partir de análisis de lámina delgada, Hocsman $(1999,2015)$ establece una serie de variables que definen la calidad para la talla de las areniscas de la Fm. Ituzaingó: tipo y cantidad de cemento, tamaño de grano y porosidad. Teniendo en cuenta estas variables, es posible trazar en primer lugar dos grandes grupos en cuanto a su utilidad para la confección de artefactos: las rocas silicoclásticas con cemento carbonático y aquellas que presentan una cementación silícea. Las primeras presentan grandes dificultades para su talla ya que, si bien pueden exhibir una buena consolidación, los planos de fractura son irregulares. Esto se debe a la menor dureza del cemento en relación al esqueleto, lo que genera que las ondas de fuerza de la percusión sean conducidas por los planos más débiles, es decir, el cemento. Las areniscas silicificadas, en cambio, poseen una mejor fractura concoide ya que el cemento silíceo opone una resistencia semejante a la de los clastos, induciendo a que la fractura atraviese el esqueleto (Jeske et al., 2010). En consecuencia, es posible asumir que las areniscas de la Fm. Paraná presentan en general una menor calidad para la talla que las areniscas silicificadas de las formaciones Ituzaingó y Salto Chico. Como ya se mencionó, estas dos formaciones son semejantes en cuanto al tamaño de grano y el tipo y la proporción de cemento, por lo que no es posible atribuir a estas formaciones diferencias en cuanto a la aptitud para la talla de sus rocas. Sin embargo, dentro de la variabilidad interna de estas formaciones, es posible distinguir rocas con diferentes calidades. Durante las pruebas de talla de las areniscas recuperadas durante los trabajos de campo, se observó que aquellas que presentan mejor fractura concoidea corresponden a las muestras en las que se observó una elevada proporción de cemento opalino, característica que brinda una elevada homogeneidad interna a la materia prima. Es interesante mencionar que estas muestras presentan un tamaño de clasto variable, sugiriendo que la cantidad y tipo de cemento pueden ser rasgos más importantes que el tamaño de grano a la hora de definir la aptitud para la talla en esta clase de rocas. Si bien el tamaño de grano es de importancia para la definición de la calidad para la talla (Bonomo y Blasi, 2010; Hocsman, 1999), las observaciones sobre ortocuarcitas de Jeske et al. (2010) indican una fuerte relevancia de la relación cemento/esqueleto en el sentido de que, a mayores proporciones de cemento, mejores posibilidades de obtener planos de fractura concoides.

A diferencia de la talla, la aptitud de las areniscas para la manufactura y uso de artefactos de molienda depende de variables diferentes. Entre las más importantes, Babot y Larrahona (2010) mencionan el tamaño de grano, la composición mineral y el tipo de cemento. La presencia de cemento silíceo brinda una mayor cohesión, pero también una mayor facilidad de fractura (Bayón, Pupio, Valente y Flegenheimer, 1999; Ratto, 1991). Dentro del subconjunto de areniscas cuarzosas con cemento carbonático, las muestras recuperadas en la Fm. Paraná presentan un menor tamaño de grano, característica que disminuiría su aptitud para la manufactura de artefactos de molienda. En cambio, las areniscas carbonáticas y silíceas de las formaciones Ituzaingó y Salto Chico, con un mayor tamaño de grano, presentarían características más útiles para la elaboración de artefactos abrasivos.

Se ha planteado que la termoalteración de materiales silíceos a altas temperaturas, cercanas al punto de estrés de las rocas (Nami et al., 2000), puede causar microfracturas en los clastos o una recristalización del sílice (Crabtree y Butler, 1964; Domanski y Webb, 1992; Purdy y Brooks, 1971) mejorando así sus propiedades de fractura concoidea y, por lo tanto, su calidad para la talla. Además, la deshidratación, oxidación y descomposición afectan los minerales de hierro produciendo cambios de color (Franzen et al., 2012; Hager, 2014). Un problema común en los estudios experimentales sobre termoalteración lítica es la gran variación registrada entre diferentes muestras de una misma roca (p. ej. rocas de una misma litología pero de diferentes formaciones), lo que ha llevado a realizar experimentaciones para cada roca en particular (Graesch, Di Mare, Schachner, Schaepe y Dallen, 2014; Jeske et al., 2010). Sin embargo, para algunas materias primas, se han podido delinear algunas tendencias generales sobre 
su comportamiento térmico. En el caso de los chert silíceos, su termoalteración modifica las características físicas de las rocas y mejora su calidad para la talla (Frank, 2011; Inizan, Roche y Tixier, 1999; Jeske et al., 2010). En cambio, los experimentos de termoalteración sobre areniscas silíceas y cuarcitas parecen indicar que el tratamiento térmico no mejora sus cualidades para la talla sino que, por el contrario, vuelven estas materias primas más frágiles e inestables (Behm y Faulkner, 1974; Inizan et al., 1999; Jeske et al., 2010). Una interpretación diferente es provista por Nami y colaboradores (2000), quienes señalan que se da una mejora en las propiedades de talla de estas rocas mediante su tratamiento térmico, en base a la experimentación sobre ortocuarcitas del grupo Sierras Bayas.

En base a los resultados alcanzados en este trabajo es posible afirmar que las areniscas de las formaciones Ituzaingó y Salto Chico cambian rápida y notablemente su color al ser sometidas a temperaturas inferiores al estrés térmico del cuarzo (véase Nami et al., 2000). En cuanto a las propiedades para la talla, se observa una pérdida de la homogeneidad del cemento silíceo y la transformación mineralógica de los minerales de hierro y arcillas. Estos cambios debilitan el cemento y conducen a que la fractura deba rodear los clastos del esqueleto en lugar de producirse por planos que lo atraviesen (Jeske et al., 2010). Esto produce un menor control de las fracturas y vuelve a las rocas más quebradizas y deleznables. Por ese motivo, la termoalteración registrada en las muestras arqueológicas posiblemente no se relacione con la intención de mejorar la calidad de la materia prima, sino que podría ser el resultado de una alteración involuntaria o accidental, o bien de la búsqueda de alterar otro tipo de propiedades de las rocas (p. ej. color).

\section{Caracterización de los recursos líticos del sur del nordeste argentino}

A continuación se resumen las principales características petrográficas de las rocas presentes en el área de estudio, teniendo en cuenta las descripciones desarrolladas en este trabajo así como también los datos proporcionados en trabajos arqueológicos previos con objetivos similares (Apolinaire et al., 2016; Bonomo y Blasi, 2010; Hocsman, 1999, 2015; Loponte et al., 2011). En el área de estudio existen distintas formaciones geológicas que presentan el mismo tipo de roca y, al mismo tiempo, una misma formación puede ofrecer diferentes clases de materias primas. Por otra parte, las características petrográficas, que varían incluso dentro de un mismo tipo de roca, brindan aptitudes diferenciales para la manufactura y uso de artefactos. Por estos motivos, las rocas no se agrupan aquí por formación geológica sino teniendo en cuenta sus aptitudes como materia prima. Además, a los fines de proporcionar una herramienta gráfica para abordar la accesibilidad de las fuentes de materias primas líticas del área de estudio, se elaboraron mapas para los distintos depósitos primarios utilizando herramientas de entorno GIS (Figuras 9 y 10). Se utilizó la información obtenida a través de las prospecciones para georreferenciar la ubicación de los afloramientos. Posteriormente, se trazaron círculos concéntricos (áreas buffer) a partir de cada afloramiento, utilizando como radio las categorías de distancia a las fuentes de aprovisionamiento propuestas por Bayón y colaboradores (2006).

Las areniscas silicificadas corresponden a arenitas cuarzosas y sublitoarenitas con tamaños de grano variable (de arena muy fina a gruesa) y elevada madurez textural y composicional. Presentan escasa o nula matriz y cemento compuesto por ópalo, calcedonia y cuarzo microcristalino. Corresponden a niveles silicificados de las formaciones Yeruá, Ituzaingó y Salto Chico. Los análisis de lámina delgada efectuados no permitieron diferenciar las areniscas silicificadas de las distintas formaciones en base a su granulometría, composición o empaquetamiento. Estas rocas presentan calidades para la talla que van de muy buenas a regulares. Se observó que el tipo y la cantidad de cemento son las principales variables que condicionan la aptitud para la talla, si bien 
no se puede descartar la relevancia del tamaño de grano y la porosidad. Además, las variedades de tamaño de grano mediano y grueso presentan características aptas para la manufactura de artefactos abrasivos.

Las areniscas silicificadas son la materia prima lítica más fácilmente accesible en la región ya que representan un recurso de acceso a media distancia para gran parte del territorio entrerriano (Figura 9A). En el río Uruguay (Fm. Salto Chico y Yeruá) estas rocas se encuentran ampliamente disponibles como niveles de arenas silicificadas de diferente espesor, color y textura. En la provincia de Entre Ríos, estos afloramientos se distribuyen en los tramos medio y superior del río Uruguay. En la cuenca del río Paraná los afloramientos de estas areniscas son más puntuales, como en el tramo inferior del arroyo Las Conchas (Hocsman, 1999), la desembocadura del arroyo Curtiembre o el arroyo La Jacinta. Es destacable el hallazgo de areniscas silicificadas y tenaces en este último arroyo, ya que si bien la Formación Ituzaingó ha sido ampliamente mencionada para las barrancas del río Gualeguay por diversos autores, hasta el momento sólo se había registrado la presencia de las facies arenosas de grano suelto (Aceñolaza, 2007; Herbst, 2000).

Las areniscas con cemento carbonático corresponden a arenitas cuarzosas, sublitoarenitas y subarcosas con tamaños de grano que van de arenas muy finas a muy gruesas. Se encuentran empaquetadas por escasa o nula matriz y cemento carbonático, compuesto principalmente por calcita. Corresponden a facies consolidadas de la Fm. Ituzaingó que afloran al norte de la ciudad de Paraná. En estos afloramientos se presentan como niveles de areniscas litificadas de diferentes espesores, intercaladas entre facies de arenas sueltas. Estas rocas también pueden encontrarse en ciertos afloramientos de la Fm. Paraná (p. ej. antigua barrera arrecifal en el Ao. Doll), donde aparecen como capas continuas y de gran extensión apoyadas sobre niveles de pelitas verdosas. La tenacidad de estas rocas, junto a su porosidad y tamaño de grano, proporcionan aptitudes muy buenas para funciones abrasivas (Hocsman, 2015). Estas rocas brindan una materia prima con una disponibilidad muy amplia y en grandes cantidades en el tramo central y norte del curso del río Paraná. Asimismo, se presentan en afloramientos más discretos en los principales tributarios de este río. Como se observa en la Figura 9B, dentro del área de estudio las areniscas carbonáticas son materias primas inmediatamente disponibles, locales y de media distancia en gran parte de la cuenca del Paraná. Si bien en este trabajo no se registraron afloramientos de areniscas carbonáticas a lo largo del río Uruguay, su presencia en las formaciones Salto y Guichón sobre la margen izquierda del río (R.O.U) es descripta por Veroslavsky y Ubilla (2007).

En el grupo de las limolitas se incluyen aquí rocas epiclásticas calcáreas de la Fm. Paraná, con granos de tamaño limo y cuyo cemento de naturaleza carbonática representa menos del 50\% de la roca. Afloran en la margen izquierda del río Paraná, en el suroeste de la provincia. Estas rocas no presentan buenas calidades para la talla ni propiedades abrasivas. Corresponden a materias primas locales e inmediatamente disponibles en el sudoeste de Entre Ríos y representan las únicas rocas de aprovisionamiento inmediato en el sector del Delta Superior del Paraná (Figura 9C).

Las rocas plutónicas y metamorfitas no poseen afloramientos detectados en la provincia de Entre Ríos. Corresponden a una gran variedad de rocas (granitos, dioritas, esquistos y gneises) de calidades para la talla regulares a malas pero de gran utilidad para la elaboración de herramientas de percusión y/o abrasión. Estas rocas afloran en la isla Martín García (Bonomo y Blasi, 2010) y en la costa oriental del río de La Plata. En la provincia de Entre Ríos sólo se encuentran disponibles localmente o a media distancia en el departamento Islas del Ibicuy, mientras que para la gran mayoría del territorio entrerriano constituyen materias primas disponibles a larga distancia (Figura 9D). 
Dentro de la denominación de calizas silicificadas se incluyen rocas que en la bibliografía arqueológica han recibido diferentes nombres: caliza silicificada, fangolita silicificada, silcretes, cherts, sílices rojos, etc. (Apolinaire et al., 2016; Bonomo y Blasi, 2010; Loponte et al., 2011; Martínez et al., 2015). Corresponden a nódulos, estratos delgados, niveles y bancos de diferentes tonalidades (rojos, blancos, negros, rosados, anaranjados y translúcidos). La gran variabilidad interna de los afloramientos en cuanto a color, tenacidad y grado de silicificación enmascara las diferencias entre afloramientos. Esto imposibilita la adscripción de las rocas a un depósito en particular, dificultando los estudios de procedencia (Martínez et al., 2015). Además, esta amplia variabilidad explica las diversas calidades para la talla registradas para estas rocas (muy buena a mala). Sobre la margen derecha del río Uruguay estas rocas se encuentran en afloramientos discretos y puntuales de la Fm. Puerto Yeruá, constituyendo una materia prima local y de media distancia en el centro oeste entrerriano (Figura 10A). Cabe destacar que los principales afloramientos de estas rocas se encuentran al otro lado del río Uruguay (departamentos de Paysandú, Río Negro, Soriano, Flores, Durazno y Canelones de la R.O.U.) (Cabrera, 2015; Martínez et al., 2015) y son indistinguibles de los afloramientos entrerrianos (Loponte et al., 2011).

Las calizas consolidadas son rocas que corresponden a afloramientos de calcretes masivos bien consolidados de la Fm. Puerto Yeruá que afloran en los departamentos Concepción y Colón (Figura 10B). Poseen en general malas calidades para la talla o la abrasión. Se incluyen aquí ya que forman parte de las rocas que han sido utilizadas como parte del arte mueble de la región de Salto Grande. Más precisamente, placas grabadas sobre estas calizas se encuentran en las colecciones del Museo de Antropología y Ciencias Naturales de la ciudad de Concordia (Apolinaire, 2017).

Las cuarcitas son rocas metamórficas que se presentan intercaladas entre coladas basálticas, en sectores puntuales de la Fm. Serra Geral (departamento Federación). Sus principales afloramientos dentro del territorio provincial se encuentran en torno al actual lago de Salto Grande. Además, por debajo de esta formación se encuentran niveles de cuarcita de la Fm. Botucatú. Estas rocas presentan una excelente calidad para la talla y tonalidades rojas, blanquecinas y translúcidas. Constituyen una materia prima disponible a larga distancia para toda la región, a excepción del noreste entrerriano (Figura 10C).

Los basaltos de la Formación Serra Geral presentan sus afloramientos en el curso medio del río Uruguay. Estas rocas generalmente presentan calidades para la talla regulares, y en algunos casos, buenas. Poseen una gran tenacidad y un peso por unidad de volumen superior a otras rocas. En este sentido, el basalto es una excelente materia prima para la manufactura de instrumentos de percusión y yunques. Por otro lado, estos basaltos tienen como huéspedes vesículas de diferentes lítologías, comúnmente silíceas (cuarzo, calcedonia y ópalo) y, en ocasiones excepcionales, metálicas (cobre). Sus afloramientos, muy localizados y discretos, constituyen fuentes de aprovisionamiento lejanas (> 100 $\mathrm{km}$ ) para la mayor parte del territorio entrerriano, al igual que en el caso anterior (Figura 10D).

El xilópalo es una materia prima que se presenta intercalada en los depósitos de arenas y areniscas de las formaciones Ituzaingó y Salto Chico. Los leños fosilizados poseen tamaños que van de pocos centímetros a varios metros y su calidad para la talla también es muy variable (muy buena a mala). Esto último depende de la estructura del leño que le dio origen, el grado de silicificación y la presencia de inclusiones.

La diversidad del registro lítico a lo largo del extenso territorio entrerriano es muy amplia, desde conjuntos como los del Delta del Paraná, donde se registran escasos artefactos elaborados sobre una amplia variabilidad de materias primas que fueron 
ligeramente modificadas, hasta conjuntos como los del curso medio del Uruguay, muy abundantes y fuertemente formatizados. Pese a los crecientes esfuerzos realizados en la última década, aun se conoce muy poco sobre los factores que dan cuenta de esta variabilidad y que condicionaron en el pasado las decisiones de aprovisionamiento y las trayectorias tecnológicas de las distintas materias primas. Esta contribución, lejos de agotar la temática, busca brindar herramientas para comprender la variabilidad de la oferta natural de rocas de la región en aspectos tales como accesibilidad, calidad para la manufactura, predictibilidad y abundancia, brindando un marco de referencia para la interpretación de los conjuntos líticos del territorio entrerriano. 


\section{Referencias citadas}

"Aceñolaza, F. (2007). Geología y recursos geológicos de la Mesopotamia Argentina. Tucumán: Consejo Nacional de Investigaciones Científicas y Técnicas, Instituto Superior de Correlación Geológica, Universidad Nacional de Tucumán.

" Apolinaire, E. (2017) Arqueología del suroeste de Entre Ríos: tecnología, subsistencia e interacción social en tiempos prehispánicos. (Tesis Doctoral inédita), Universidad Nacional de La Plata, Argentina.

》 Apolinaire, E. (en prensa). Caracterización de los depósitos secundarios de rodados fluviales del río Uruguay inferior. Su aplicación en contextos arqueológicos de las llanuras interiores del nordeste argentino. Boletim do Museu Paraense Emílio Goeldi. Ciências Humanas.

"Apolinaire, E., Bastourre, L. y Angrizani, R. (2016). Arqueología de las tierras altas de Entre Ríos: primeros resultados de las prospecciones en el interior del departamento Gualeguay. Intersecciones en Antropología, 17(1), 91-107.

"Apolinaire, E. y Castiñeira, C. (en prensa). Primeros estudios arqueológicos y sedimentológicos de un contexto estratigráfico en el interior entrerriano. El sitio Laguna del Negro 1. Comechingonia. Revista de Arqueología.

" Babot, M. y Larrahona, P. (2010). Artefactos de molienda y materias primas. Relaciones de la Sociedad Argentina de Antropología, XXXV, 17-40.

" Bastourre, L. y Apolinaire, E. (2017). Estudios arqueofaunísticos en un contexto estratigráfico de las llanuras interiores de Entre Ríos: el sitio Laguna del Negro 1 (departamento Gualeguay, Argentina). Boletim do Museu Paraense Emílio Goeldi Ciências Humanas, 12(2), 453-417.

» Bayón, C., Pupio, A., Valente, M. y Flegenheimer, N. (1999). Dime cómo eres y te diré de dónde vienes: procedencia de rocas cuarcíticas en la Región Pampeana. Relaciones de la Sociedad Argentina de Antropología, XXIV, 187-219.

» Bayón, M., Flegenheimer, N. y Pupio, A. (2006). Planes sociales en el abastecimiento y traslado de roca en la pampa bonaerense en el Holoceno temprano y tardío. Relaciones de la Sociedad Argentina de Antropología, XXXI, 19-45.

" Behm, J. y Faulkner, A. (1974). Hixton quartzite: experiments in heat treatment. The Wisconsin Archaeologist, 55(4), 271-276.

》 Bertolini, J., Bahler, G. y Zabalegui, M. F. (2009). La costa entrerriana del río Paraná. Un compendio de su historia natural. En Sitios de Interés Geológico de la República Argentina (pp. 427-435). Buenos Aires: Servicio Geológico Minero Argentino (SEGEMAR).

" Best, M. (2003). Igneous and metamorphic petrology. Nueva York: John Wiley \& Sons.

» Bonomo, M. y Blasi, A. (2010). Base regional de recursos líticos del Delta del Paraná. Estudio petrográfico de artefactos y afloramientos en el sur de Entre Ríos. Revista Cazadores Recolectores del Cono Sur, 4(1), 17-41.

" Bravard, A. (1858). Monografía de los terrenos marinos terciarios del Paraná. Buenos Aires: El Nacional Argentino.

" Brunetto, E., Noriega, J. y Brandoni, D. (2013). Sedimentología, estratigrafía y edad de la Formación Ituzaingó en la provincia de Entre Ríos, Argentina. En D. Brandoni y J. Noriega (Eds.), El Neógeno de la Mesopotamia Argentina (pp. 13-27). Buenos Aires: Publicación Electrónica de la Asociación Paleontológica Argentina. 
"Buc, N., y Silvestre, R. (2010). Distribución de artefactos líticos y óseos en el humedal del Paraná inferior. En G. Cocco y M. Feuillet Terzaghi (Eds.), Arqueología de Cazadores recolectores de la Cuenca del Plata. Santa Fe: Centro de Estudios Hispanoamericanos.

»Castro, J. (2012). Arqueología en el Parque Nacional El Palmar (Entre Ríos, Argentina): disponibilidad y explotación de materias primas líticas). Intersecciones en Antropología, 13(1), 145-161.

" Castro, J. (2013). Arqueología del centro de la provincia de Entre Ríos (Argentina). Arqueología, 19(2), 287-304.

» Castro, J.yAngrizani, R. (2014). El sitio arqueológico Ensenada del Bellaco (Gualeguaychú, Entre Ríos) como indicador de la presencia guaraní en el río Uruguay Inferior. Revista del Museo de Antropología, 7(2), 235-242.

» Crabtree, D. y Butler, D. (1964). Notes on experiments in flintknapping: 1. Heat treatment of silica materials. Tebiwa, 7(1), 1-6.

» Dalla Salda, L. (1999). Cratón del Río de la Plata, 1: Basamento granítico-metamórfico de Tandilia y Martín García. En Geología Argentina (pp. 97-106). Buenos Aires: Subsecretaría de Minería.

»De Alba, E. y Serra, N. (1959). Aprovechamiento del río Uruguay en la zona de Salto Grande: informe sobre las condiciones y características geológicas. Manuscrito inédito.

»Domanski, M. y Webb, J. (1992). Effect of heat treatment on siliceous rocks used in prehistoric lithic technology. Journal of Archaeological Science, 19(6), 601-614.

»Franco, M. (2012). Maderas fósiles de Lauraceae de la Formación Ituzaingó (PliocenoPleistoceno), cuenca del río Paraná, Argentina. Revista del Museo Argentino de Ciencias Naturales, 14(2), 307-324.

» Frank, A. (2011). Tratamiento térmico y manejo del fuego en sociedades cazadorasrecolectoras de la Meseta Central de Santa Cruz. (Tesis Doctoral inédita), Universidad Nacional de La Plata, Argentina.

» Franzen, C., Krause, D., Siedel, H. y Ullrich, B. (2012). Temperature Impact in Cotta Sandstone. Proceedings of 12th International Congress on the Deterioration and Conservation of Stone, Columbia University, Nueva York.

» Frost, B. y Frost, C. (2014). Essentials of igneous and metamorphic petrology. Cambridge: Cambridge University Press.

» Folk, R. (1980). Petrology of sedimentary rocks. Austin: Hemphill Publishing Company.

» Garrison, E. (2016). Techniques in Archaeological Geology. Berlin: Springer.

" Gentili, C. y Rimoldi, H. (1979). Mesopotamia. Segundo Simposio Geología Regional Argentina, Academia Nacional de Ciencias, 1(1), 185-223.

" Graesch, A., Di Mare, T., Schachner, G., Schaepe, D. y Dallen, J. (2014). Thermally Modified Rock: The Experimental Study of "Fire-Cracked" Byproducts of Hot Rock. North American Archaeologist, 35(2), 1-15.

» Goso, H. (1965). The Cenozoic in Uruguay. Buenos Aires: Eudeba.

»Hager, I. (2014). Sandstone colour change due to the High Temperature Exposure. En Advanced Materials Research (pp. 411-415). Nueva York: Trans Tech Publications.

» Herbst, R. (1971). Esquema estratigráfico de la provincia de Corrientes, República Argentina. Revista de la Asociación Geológica Argentina, 26(2), 221-243.

» Herbst, R. (2000). La Formación Ituzaingó (Plioceno). Estratigrafía y distribución. En F.G. Aceñolaza y R. Herbst (Eds.). El Neógeno de Argentina (pp. 181-19o). Buenos Aires: INSUGEO. 
"Hocsman, S. (1999). Tecnología lítica prehispánica en la cuenca inferior del arroyo Las Conchas (Depto. de Paraná, Pcia. de Entre Ríos): El sitio VU 4 como caso de estudio. (Tesis de grado inédita), Universidad Nacional de Tucumán, Argentina.

» Hocsman, S. (2015). Caracterización petrográfica y calidades de areniscas (margen entrerriana del Paraná medio). Revista de Antropología del Museo de Entre Ríos, 1(1), 1-15.

» Inizan, M., Roche, H. y Tixier, J. (1999). Terminology and technology of knapped Stone. Meudon: CNRS.

» Iriondo, M. (1973). Análisis ambiental de la Formación Paraná en su área tipo. Boletín de la Asociación Geológica de Córdoba, 2(1-2), 19-23.

»Iriondo, M. y Kröhling, D. (2008). Cambios ambientales en la cuenca del Uruguay (desde el Presente hasta dos millones de años atrás). Santa Fe: Universidad Nacional del Litoral.

» Jeske, R., Winkler, D. y Blodgett, D. (2010). Experimental Heat Alteration of L Lithic Raw Materials. En J. Ferguson (Ed.), Designing Experimental Research in Archaeology. Colorado: University Press of Colorado.

» Kompaniková, Z., Gomez-Heras, M., Mich ová, J., Durmeková, T. y VI ko, J. (2014). Sandstone alterations triggered by fire-related temperatures. Environmental Earth Sciences, 72(7), 2569-2581.

» Loponte, D., Tchilinguirian, P. y Silvestre, R. (2011). Caracterización de afloramientos de calizas silicificadas de la provincia de Entre Ríos (Argentina) y su vinculación con los circuitos de abastecimiento prehispánico. En M. R. Feuillet Terzaghi, M. Belén Colasurdo, J. I. Sartori y S. Escudero (Eds.), Avances y perspectivas en la arqueología del Nordeste (pp. 125-140). Buenos Aires: ST Servicios Gráficos.

» Martínez, S., Veroslavsky, G. y Cabrera, F. (2015). Calizas del Queguay: Un enfoque hacia la arqueología. Revista de Antropología del Museo de Entre Ríos, 1(2), 1-10.

" Mazzoni, M. (1977). El uso de medidas estadísticas texturales en el estudio ambiental de arenas. Obra Centenario Museo La Plata, 4, 261-283.

» Nami, H., Cattáneo, G. y Pupio, M. (2000). Investigaciones experimentales sobre el tratamiento térmico en algunas materias primas de Pampa y Patagonia. Anales del Instituto de la Patagonia, 28, 315-329.

»Pérez, L. (2013). Sistemática, tafonomía y paleoecología de los invertebrados de la formación Paraná (Mioceno), provincia de Entre Ríos, Argentina. (Tesis Doctoral inédita), Universidad Nacional de La Plata, Argentina.

»Pérez Jimeno, L. (2010). Tecnología lítica en la llanura aluvial del Paraná medio. En G. Cocco y M. Feuillet Terzaghi (Eds.), Arqueología de Cazadores recolectores de la Cuenca del Plata. Santa Fe: Centro de Estudios Hispanoamericanos.

》Pettijohn, F. (1989). Rocas Sedimentarias. Buenos Aires: Eudeba.

»Purdy, B. y Brooks, H. (1971). Thermal alteration of silica minerals: an archaeological approach. Science, 173, 322-325.

"Ratto, N. (1991). Elección de roca y diseño de artefactos: propiedades físico-mecánicas de los artefactos de las materias primas líticas del sitio IC-c4, Argentina. En H. Niemeyer (Ed.), Actas del XI Congreso Nacional de Arqueología Chilena (pp. 121-137). Sociedad Chilena de Arqueología: Santiago de Chile.

" Rimoldi, H. (1962). Aprovechamiento del río Uruguay en la zona de Salto Grande. Primeras Jornadas Geológicas Argentinas, 287-310.

» Rodríguez, J. (2001) Nordeste Prehispánico. En E. Berberián y A. Nielsen (Eds.), Historia Argentina Prehispánica. Cordoba: Editorial Brujas. 
» Roduit, N. (2007). JMicroVision: Image analysis toolbox for measuring and quantifying components of high-definition images. Version 1.2.2. http://www.jmicrovision.com (Acceso: 15 de marzo de 2018).

»Santa Ana, H., Veroslavsky, G., Etchebehere, M. y Saad, A. (2013). Evaluación del potencial mineral de los recursos calcáreos de la región del litoral oeste de Uruguay (Formacion Queguay, Cuenca Paraná). Revista Geociências-UnG, 8(6), 15-29.

»Silva Busso, A. y Fernandez Garrasino, C. (2004). Presencia de las Formaciones Piramboia y Botucatú (Triásico-Jurásico) en el subsuelo oriental de la provincia de Entre Ríos. Revista de la Asociación Geológica Argentina, 59(1), 141-151.

"Swanson, R. (1991). Sample examination manual. Oklahoma: The American Association of Petroleum Geologists.

» Tófalo, O. y Morrás, H. (2009). Evidencias paleoclimáticas en duricostras, paleosuelos y sedimentitas silicoclásticas del Cenozoico de Uruguay. Revista de la Asociación Geológica Argentina, 65(4), 674-686.

» Tófalo, O. y Pazos, P. (2002). Caracterización de calcretes de la Formación Puerto Yeruá (Cretácico), en base a su micromorfología (Entre Ríos, Argentina). Revista de la Asociación Argentina de Sedimentología, 9(2), 127-134.

» Tófalo, O., Pazos, P. y Bettucci, L. (2011). Estudio composicional de sedimentitas silicoclasticas y paleosuelos de la formación Mercedes (Cretácico Superior), Uruguay. Revista de la Asociación Geológica Argentina, 68(4), 615-626.

» Tonni, E. (1987). Stegomastodon platensis (Mammalia, Proboscidea, Gomphotheriidae) y la antigüedad de la Formación El Palmar en el Dto. de Colón, prov. de Entre Ríos, Argentina. Ameghiniana, 24(3-4), 323-324.

"Torra, R. (1999). Sedimentología de las arenas de la Formación Ituzaingó, en el sector norte y este de la Mesopotamia, Argentina. (Tesis Doctoral inédita), Universidad Nacional de Tucumán, Argentina.

» Torra, R. (2009). Sedimentología y estratigrafía de las formaciones Paraná, Ituzaingó, Toropí, Yupoí y Puelches (Mioceno medio), Mesopotamia de Argentina: consecuencias para la edad de las mismas. Revista de la Universidad del Nordeste, 4, 1-15.

» Tucker, M. (2002). Sedimentary rocks in the field. Nueva York: Wiley \& Sons Ltd.

» Tucker, M. (2003). Sedimentary petrology: an introduction to the origin of sedimentary rocks. Nueva York: John Wiley \& Sons.

»Veroslavsky, G. y Ubilla, M. (2007). A 'snapshot' of the evolution of the Uruguay River (Del Plata Basin): the Salto depositional sequence (Pleistocene, Uruguay, South America). Quaternary Science Reviews, 26(22), 2913-2923.

» von Huene, F. (1929). Los saurisquios y ornitisquios del Cretáceo Argentino. La Plata: Universidad Nacional de la Plata, Museo de La Plata.

» Zucol, A., Brea, M., Lutz, A. y Anzotegui, L. (2004). Aportes al conocimiento de la paleodiversidad del Cenozoico Superior del Litoral Argentino: estudios paleorísticos. Miscelanea, 21(1), 91-102. 